\title{
The Middle and Upper Devonian conodont sequence from La Guardia D'Àres Sections (Spanish Central Pyrenees)
}

\author{
JAU-CHYN LIAO \& JOSÉ I. VALENZUELA-RÍOS
}

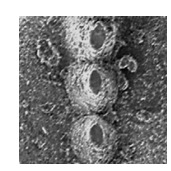

\begin{abstract}
The analysis of conodont faunas from the Comabella Formation at La Guardia d'Àres in the Spanish Central Pyrenees improves the biostratigraphical characterization of this stratum. Forty-seven taxa spanning from the Eifelian through the Lower Frasnian are identified and described. The lower part of the formation starts in the Eifelian kockelianus Zone. The Eifelian/Givetian boundary can be identified by the entry of the index taxon Polygnathus hemiansatus. The Givetian part of the section is tectonically disturbed, affecting mostly the confident recognition of the rhenanus/varcus and the Upper varcus zones. All other Givetian zones are identified either by the defining index taxa or by the characterizing taxa. The Ancyrodella sequence permits recognition of Lower Frasnian MN1-MN3 zones. Direct comparison with Boersma's data shows a strong chronostratigraphical discrepancy and their data are reinterpreted. Key words: Middle Devonian, Lower Frasnian, conodont biostratigraphy, Spanish Central Pyrenees.
\end{abstract}

LiAO, J.-C. \& VAlEnZUElA-Ríos, J.I. 2013. The Middle and Upper Devonian conodont sequence from La Guardia D’Àres Sections (Spanish Central Pyrenees). Bulletin of Geosciences 88(2), 339-368 (8 figures). Czech Geological Survey, Prague. ISSN 1214-1119. Manuscript received February 22, 2012; accepted in revised form June 12, 2012; published online February 26, 2013; issued June 7, 2013.

Jau-Chyn Liao (corresponding author), Departamento de Paleontología, Facultad de Ciencias Geológicas, Universidad Complutense de Madrid; c/ Antonio Novais 2, 28040 Madrid, Spain; jau.liao@uv.es • Jau-Chyn Liao \& José I. Valenzuela-Ríos, Departamento de Geología, Universitat de València, c/Dr. Moliner 50, 46100 Burjasot, Spain; jose.i.valenzuela@uv.es

Detailed work on Middle and early Upper Devonian strata from the Spanish Central Pyrenees carried out in the last decade has provided a detailed, conodont-based, Givetian and early Frasnian biozonation that can be correlated worldwide (Liao et al. 2001; Liao et al. 2008; Liao \& Valenzuela-Ríos 2008, 2012; Gouwy et al. 2013). This biozonation is based in sections from three different subfacies areas (in the sense of Mey 1967): Section Renanué from Subfacies Renanué (Liao et al. 2001, 2008); Section Compte (Liao \& Valenzuela-Ríos 2008) and Section Villech (Gouwy et al. 2013) from Subfacies Compte, and Section Ampriú from Subfacies Sierra Negra (Liao \& Valenzuela-Ríos 2012). In spite of the general wealth of the conodont record, each section shows intervals that are not as well characterized as desirable for fine biostratigraphical correlation. A solution to such problems is detailed analysis of as many sections as possible and to integrate the data into the Pyrenean network which is under construction.

One potential area for improving the current Pyrenean knowledge on the Devonian conodont sequence is the set of outcrops known as La Guardia d'Àres sections. The major aims of this report are to document in detail the conodont sequence for the upper Eifelian to the early Frasnian strata from La Guardia d'Àres and to integrate these data into the Pyrenean and global networks. Additionally, a detailed study of the Givetian/Frasnian boundary is also pursued.

\section{Geological setting}

The La Guardia d'Àres outcrop area is located about $1.5 \mathrm{~km}$ east of the La Guardia d'Àres village, on the recently paved road connecting the valleys of the Segre and Noguera Pallaresa rivers between Navas de Segre and Gerri de la Sal (Fig. 1).

Boersma (1973) described this area for first time; he established the stratigraphical sequence and partially dated these rocks. He recognized the upper part of the Basibé Fm. (Lower Devonian), the Villech Fm. (Lower to Middle Devonian), the three Members $(\mathrm{A}-\mathrm{C})$ of the Compte Fm. (Middle Devonian-Carboniferous) and the lowermost part of the overlying Bellver Fm. (Carboniferous). 


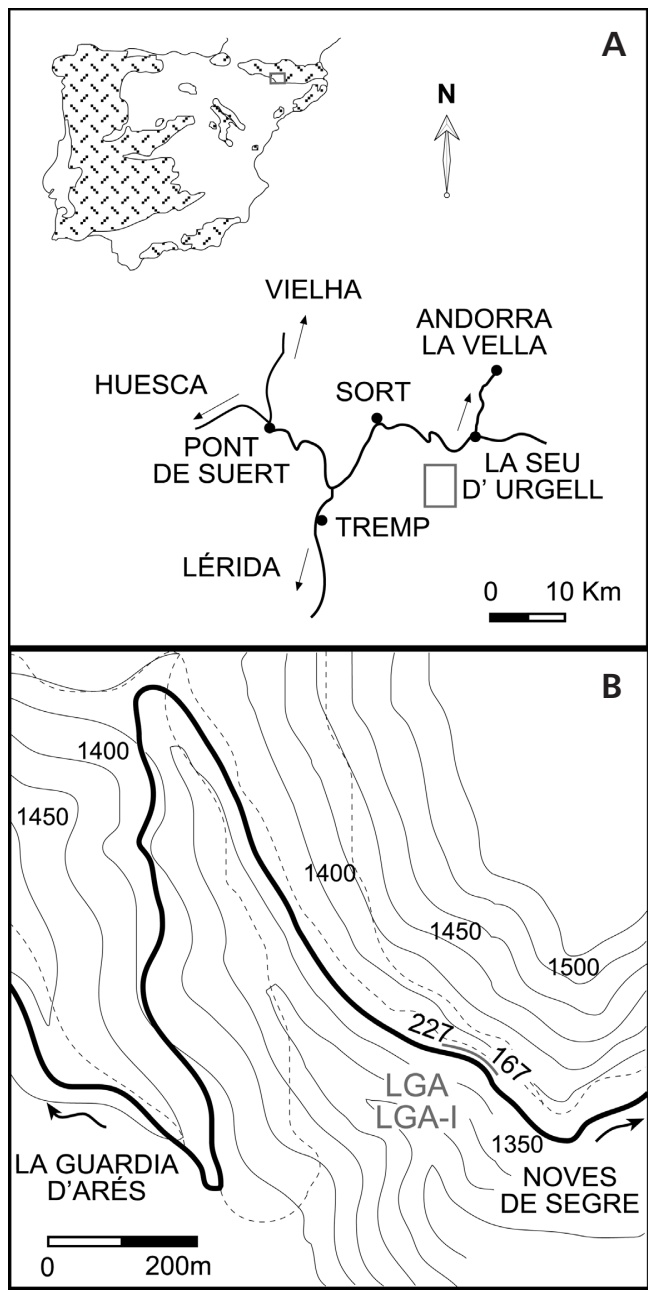

Figure 1. General (A) and detailed geographical setting of the La Guardia d'Àres section (LGA) in the Spanish Central Pyrenees (B). Numbers indicate the position of the lower (167) and the upper (227) Beds in LGA section. Section LGA-I is less than $2 \mathrm{~m}$ higher in the same hill at the position of the upper part of LGA.

The lower part of the section (Basibé and Villech formations) has already been studied (Martínez-Pérez et al. 2011). Herein, we will focus in the part corresponding to the Member A of the Compte Fm. that in current stratigraphic nomenclature is the Comabella Fm. According to Boersma (1973) this stratigraphical interval comprises from the Polygnathus kockelianus Zone (Eifelian) to the P. asymmetricus Zone (Frasnian). He was able to identify the Givetian Icriodus obliquimarginatus and $P$. varcus zones, but he failed in recognizing the Upper Givetian hermanni and cristatus zones, even though he identified Schmidtognathus hermanni in sample 132 (Boersma 1973, p. 318); he considered this record as belonging to the $P$. varcus Zone (Boersma, op. cit.)
We have been able to identify some of Boersma's sample numbers and they can be directly correlated with our sampling for data comparison and subsequent bio-and chronostratigraphical interpretation.

The studied part (Fig. 2) measures about $40 \mathrm{~m}$ thick and is composed of reddish-pinkish and light grey nodular and platy limestone; the lower beds are platy; beds in the middle parts are thicker and massive with wavy surfaces; in the upper part the limestone beds are thin again, but thicker than the lower part.

The detailed fieldwork carried out in the area shows that this section is tectonically affected and several minor faults and a fold hinder a continuous record. The detailed sampling was needed for checking the tectonically affected intervals.

Besides the main section (LGA), we have sampled an auxiliary parallel section (LGA-I) for better characterizing the Givetian-Frasnian interval. The relative position of these two sections is documented in Figs 1 and 2.

\section{Results}

The conodont sequence allows assignation of the studied strata to a time span from the Eifelian to the Lower Frasnian and the identification of many of the main global conodont zones for this interval. Most data come from LGA section, but for the interval around the Givetian/Frasnian boundary an auxiliary section (LGA-I) was also studied.

\section{LGA section}

\section{Eifelian (Fig. 3A)}

The lower part of the LGA section is Eifelian in age, but a precise zonation cannot be established (Beds 167-179; Fig. 3A). The dominant taxon is Polygnathus linguiformis linguiformis that has an ample range spanning from the lower part of the Eifelian (costatus Zone) through the Middle Frasnian (MN 7 Zone). The presence of P. l. klapperi in the basal Bed (167) limits the age to the upper Eifelian kockelianus Zone. The last local records of $P$. costatus and $P$. oblongus in the Bed 168 correspond to the upper part of their ranges (kockelianus Zone). Another common taxon of the Eifelian part in LGA is $P$. angustipennatus, which records here correspond to the upper part of its range (Beds 174-179); the related taxon $P$. angusticostatus that according to Walliser \& Bultynck (2011) is almost restricted to the Eifelian (costatus-base of hemiansatus zones), appears

Figure 2. Lithological columns of LGA and LGA-I sections with indication of the stratigraphy at the eastern limb of the fold, the conodont samples (arrows), the conodont distribution and the chronostratigraphical interpretation. 
Jau-Chyn Liao \& José I. Valenzuela-Ríos • The Middle and Upper Devonian conodonts from the Central Pyrenees

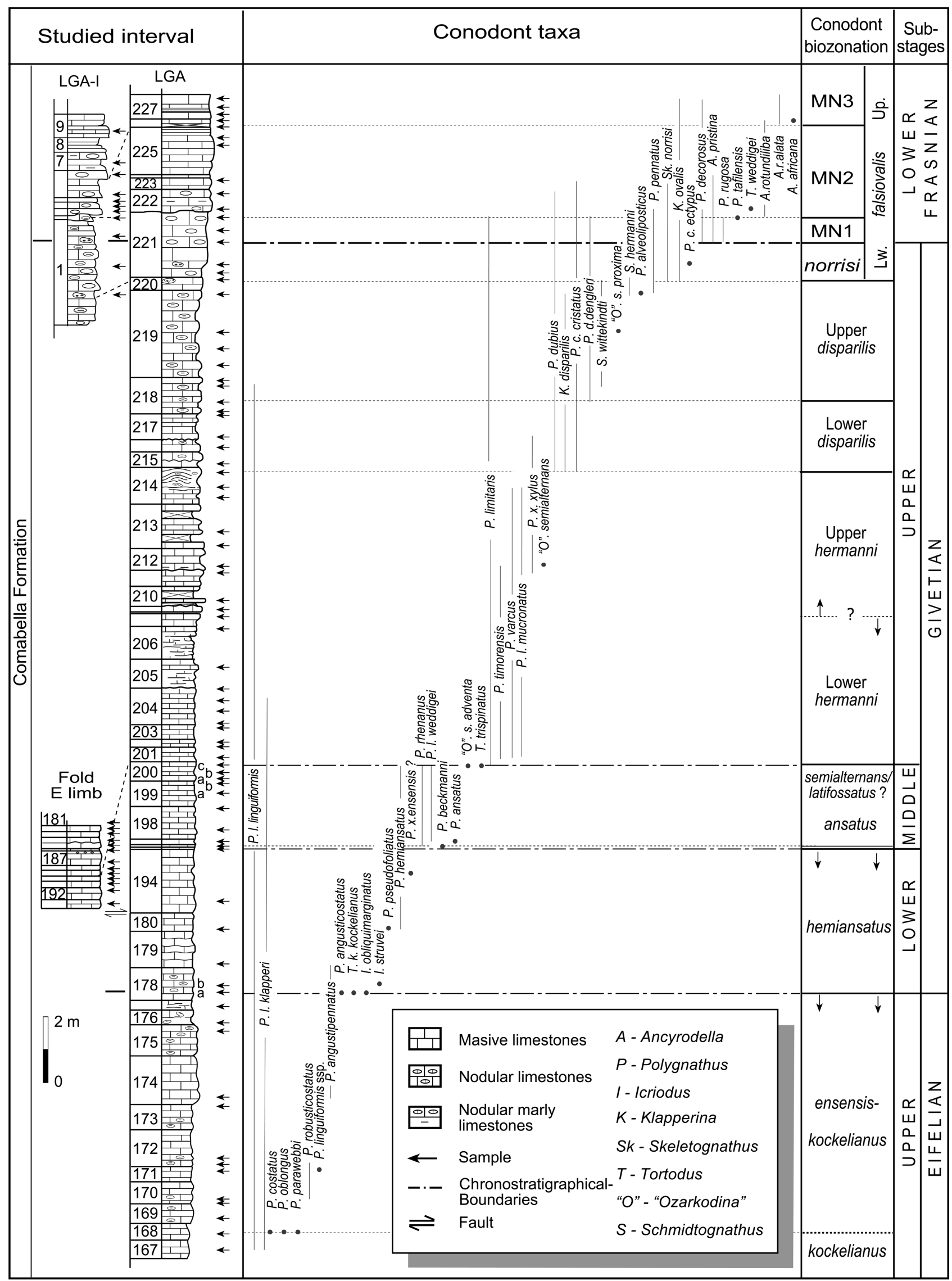


in sample 178a. Icriodus struvei (Bed 178b) mirrors the range of $P$. angustipennatus. The presence in sample 178a of I. obliquimarginatus, which ranges in Morocco from the base of the hemiansatus Zone (Walliser \& Bultynck 2011, p. 17) suggests tentatively assignation of this Bed to the base of the hemiansatus Zone, and therefore, the beginning of the Givetian.

In brief, the Eifelian is represented in Beds 167-177 and they belong to the two upper Eifelian conodont zones, kockelianus and ensensis, but the position of the boundary cannot be recognized. Therefore, we grouped all these beds under the comprehensive kockelianus-ensensis term.

\section{Givetian}

Lower Givetian: hemiansatus Zone (Fig. 3A). - The Givetian starts with the entry of I. obliquimarginatus in sample 178a. The lowest record of the index taxon $P$. hemiansatus is delayed (Bed 180). P. pseudofoliatus is also recorded from this bed. The upper part of this bed is tectonically disrupted by a normal fault. The rocks outcropping above this fault depict a fold that comprises strata from the Lower varcus to the Lower hermanni zones. Due to the biostratigraphical interest of this section and the tectonical disruption at this point, both limbs of the fold were sampled for a detailed checking of the strata age. The results are grouped into west and east limbs respectively (Fig. 3). The sample numbering of the western limb comprises Beds 195 to 201, while those from the eastern limb are, in stratigraphical order, from Bed 193 (older) to 181 (younger; the fold limb is not inverted, just the numbering is reversed).

Western limb:

Middle Givetian: ansatus Zone (Fig. 3A). - Bed 195 does not have a definitive age, as the only record is the long-ranging taxon P. l. linguiformis. Bed 196 yielded $P$. rhenanus and $P$. beckmanni; the former starts in the rhenanus/varcus Zone, but the latter does not appear before the ansatus Zone; consequently these records are interpreted as belonging to the Middle Givetian ansatus Zone. The index of this zone ( $P$. ansatus) enters in the overlying bed (197); samples 196 and 197 are separated by only $4 \mathrm{~cm}$. Polygnathus l. linguiformis, $P$. l. klapperi and the lowest local record of $P$. $l$. weddigei complete the conodont diversity of Bed 197.

Upper Givetian: hermanni Zone (Fig. 3A). - The association of Tortodus trispinatus and $P$. limitaris in sample 200c suggests that it belongs to the Lower hermanni Zone as the upper known range of the former does reach beyond the Lower hermanni Zone and the range of the latter starts at the hermanni Zone. The association of $P$. l. mucronatus and "Ozarkodina" sannemanni adventa in the overlying bed (201), permits assignation of this bed to the Lower hermanni Zone, as well. The uppermost range of the former taxon is known from the hermanni Zone and the latter starts in this zone. Other taxa from this bed, P. l. linguiformis, $P$. l. klapperi and $P$. varcus, have longer ranges.

In summary, Beds 195 to 201 in the west limb of the fold cover an interval from the Middle Givetian ansatus Zone to the Upper Givetian Lower hermanni Zone, but only these two zones are identified. The semialternans/latifossatus Zone that shall be located between them has not been identified and has to be found in some place between samples containing the index and characterizing conodonts mentioned above (197 and 200c respectively).

Eastern limb:

Middle-Upper Givetian: ansatus-Upper varcus-hermanni zones (Fig. 3B). - Polygnathus l. linguiformis is present in all samples of this limb. The lowest sample (193) yielded $P$. rhenanus, which has a restricted range from the rhenanus/varcus Zone to the uppermost part of the ansatus Zone; but Aboussalam (2003) extends its range into the semialternans/latifossatus Zone. Lack of definitive records from Beds 192-191 does not allow greater precision. However, the identification of the hermanni Zone (see below) in Bed 189, which lays $60 \mathrm{~cm}$ above Bed 193, hints at a tentatively position of Bed 193 within the upper part of the $P$. rhenanus range, probably in the ansatus Zone, but definitive evidence is pending.

The hermanni Zone could be identified in Bed 189 by the presence of "O." sannemanni adventa, which globally starts in this zone. However, there are records of two taxa that do not fit well with this interpretation. Also in Bed 189 $P$. hemiansatus and $P$. rhenanus are recorded; both taxa normally disappear within the Upper varcus Zone or earlier (P. rhenanus, see above); therefore, their joint occurrence with conodonts indicative of the younger hermanni Zone is puzzling. Records of the overlaying beds (188-181) do not help to sort out this uncertainty.

\section{Upper Givetian: hermanni-norrisi Zones (Figs 4, 5). -}

hermanni Zone (Fig. 4). The LGA section continues from the western limb upward, and consequently the numbering follows this order, being the next sample from Bed 202. The yields of the next $8 \mathrm{~m}$ thick set of beds (202-214b) is dominated by $P$. l. linguiformis, and $P$. l. klapperi, the upper range of the later, which last occurs in Bed 204, ends either in the hermanni Zone or in the succeeding disparalis Zone. Other common taxa in this interval, $P$. xylus xylus, $P$. varcus, and $P$. timorensis, have larger ranges that hinder further precision. The spotty occurrences of taxa with more restricted ranges, such as $P$. l. mucronatus (Bed 214b) and “O.” semialternans (Bed 212), only 


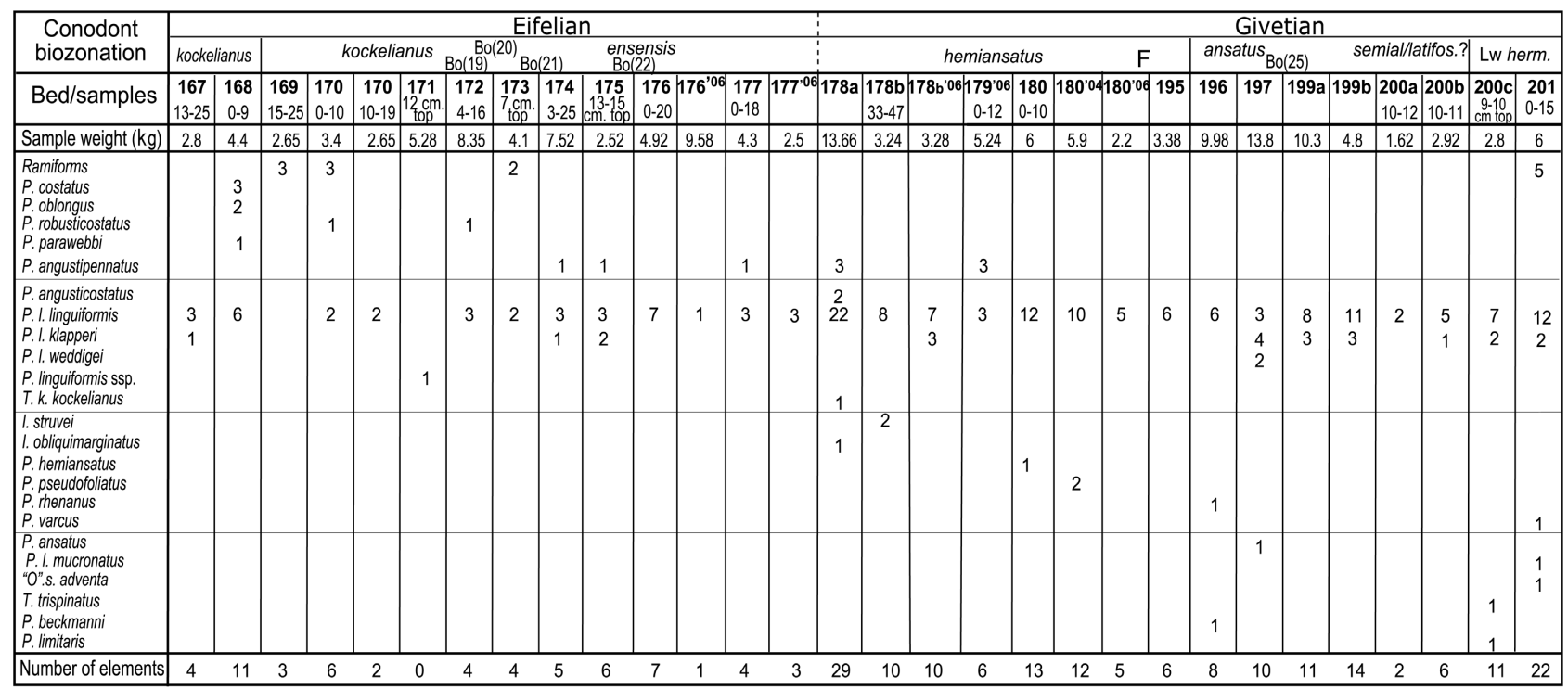

A

Figure 3. Distribution of conodont species and richness in LGA section from the kockelianus to the Lower hermanni Zone. - A indicates the sequence on the western limb above the fault $(\mathrm{F}) \cdot \bullet \mathrm{B}$ corresponds to the eastern limb of the fold. Bo (19-25) indicates the position of the Boersma (1973) samples.
B

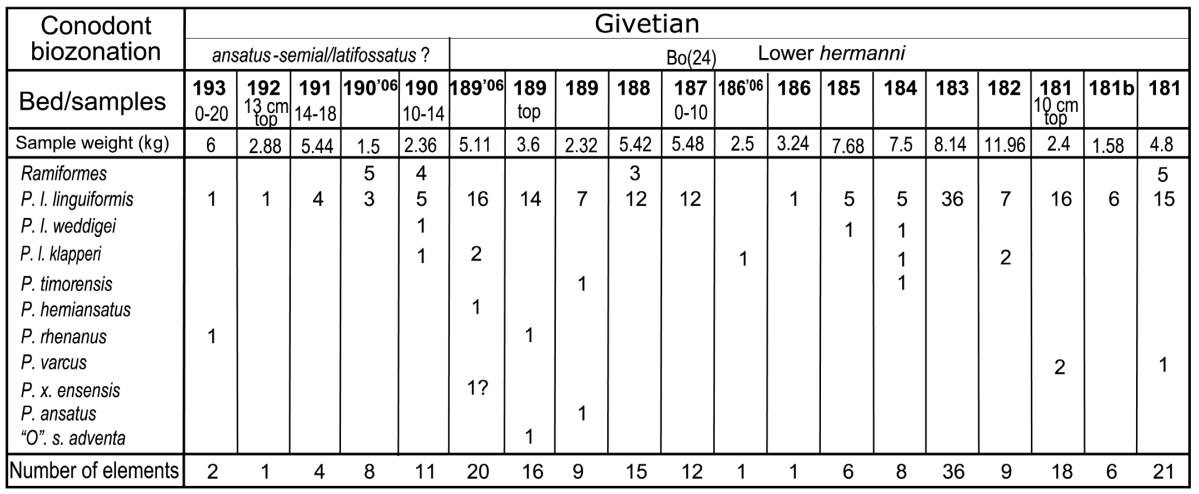

\begin{tabular}{|c|c|c|c|c|c|c|c|c|c|c|c|c|c|c|c|c|c|c|c|c|c|c|c|c|c|c|c|c|}
\hline \multirow{3}{*}{$\begin{array}{c}\begin{array}{c}\text { Conodont } \\
\text { biozonation }\end{array} \\
\text { Bed/Sample }\end{array}$} & \multicolumn{28}{|c|}{ Givetian } \\
\hline & \multicolumn{6}{|c|}{ Lower hermanni } & \multicolumn{5}{|l|}{$\mathrm{Bo}(27)$} & \multicolumn{3}{|l|}{ Bo(28) } & \multicolumn{9}{|c|}{ Upper hermanni? } & \multicolumn{5}{|c|}{ Lower disparilis } \\
\hline & \begin{tabular}{|r|}
$202 \mathrm{a}$ \\
$5-9$
\end{tabular} & $\begin{array}{c}202 \mathrm{a}^{\prime} 0 \\
5-9\end{array}$ & $\begin{array}{l}202 \mathrm{~b} \\
10-13 \\
\mathrm{~cm} \text { top }\end{array}$ & \begin{tabular}{|c|}
$\mathbf{2 0 3}$ \\
$3-11$ \\
cm top \\
\end{tabular} & \begin{tabular}{|r|}
204 \\
$5-17$ \\
\end{tabular} & \begin{tabular}{r|r|}
204 \\
$17-23$
\end{tabular} & \begin{tabular}{|c|}
204 \\
$24-37$ \\
\end{tabular} & \begin{tabular}{|l|}
204 \\
top
\end{tabular} & \begin{tabular}{|c|}
205 \\
$12 \mathrm{~cm}$ \\
top
\end{tabular} & \begin{tabular}{|c|}
$205^{\prime} 06$ \\
$12 \mathrm{~cm}$ \\
top
\end{tabular} & \begin{tabular}{|c|}
206 \\
$6 \mathrm{~cm}$ \\
top
\end{tabular} & $\begin{array}{r}207 \\
10 \mathrm{~cm} \\
\text { top }\end{array}$ & 208 & \begin{tabular}{|c|}
209 \\
$7 \mathrm{~cm}$ \\
top
\end{tabular} & 210 & 211 & \begin{tabular}{|l|}
212 \\
$0-22$ \\
\end{tabular} & \begin{tabular}{r|}
$212^{\prime} 06$ \\
$0-22$
\end{tabular} & $213 a$ & $213 a^{\prime} 04$ & $34213 b^{\prime} 04$ & \begin{tabular}{|c|}
$214 \mathrm{a}$ \\
$10 \mathrm{~cm}$ \\
top
\end{tabular} & \begin{tabular}{|c|}
$214 \mathrm{~b}$ \\
$10 \mathrm{~cm}$ \\
top
\end{tabular} & \begin{tabular}{|c|}
$214 \mathrm{c}$ \\
$8 \mathrm{~cm}$ \\
top
\end{tabular} & $214 c^{\prime} 0$ & \begin{tabular}{|l|}
$216 a$ \\
$0-20$
\end{tabular} & $216 a^{\prime} 06$ & $6216 \mathrm{~b}$ \\
\hline Sample weight $(\mathrm{kg})$ & \begin{tabular}{|l|}
2.38 \\
\end{tabular} & 3.4 & 2.4 & 2.52 & 5.68 & 3.72 & 6.94 & 3.96 & 3 & 2.35 & \begin{tabular}{|l|}
3.18 \\
\end{tabular} & 3.98 & 3.32 & 2.56 & 12.1 & 3.06 & 2.64 & 3.4 & 3 & 8.44 & 10.41 & 4.4 & \begin{tabular}{|l|}
6.5 \\
\end{tabular} & 6.7 & 3 & 7.24 & 3.52 & 5.5 \\
\hline $\begin{array}{l}\text { Ramiforms } \\
\text { P. I. linguiformis } \\
\text { P. I. klapperi } \\
\text { P.x. xylus } \\
\text { P. varcus } \\
\text { P. timorensis } \\
\end{array}$ & $\begin{array}{l}3 \\
1\end{array}$ & $\begin{array}{l}5 \\
4\end{array}$ & 2 & 1 & 1 & 1 & 6 & 2 & 4 & 3 & 2 & 4 & 5 & 1 & 1 & $\begin{array}{l}5 \\
2 \\
1\end{array}$ & 3 & $\begin{array}{l}10 \\
2 \\
1\end{array}$ & 3 & 8 & 7 & 2 & $1 ?$ & & & & & $\begin{array}{l}2 \\
1\end{array}$ \\
\hline $\begin{array}{l}\text { P. pseudofoliatus } \\
\text { P. I. mucronatus } \\
\text { "O". semialternans } \\
\text { P. dubius } \\
\text { P. c. cristatus } \\
\text { K. disparilis } \\
\end{array}$ & & & & & & & & & & & & & & & & & & 1 & & & & & 1 & $\begin{array}{l}1 \\
4 \\
3 \\
3\end{array}$ & $1 ?$ & 1 & $\begin{array}{l}2 \\
2 \\
\end{array}$ & 2 \\
\hline Number of elements & 4 & 9 & 2 & 1 & 1 & 1 & 6 & 2 & 4 & 3 & 2 & 5 & 5 & 1 & 2 & 8 & 3 & 14 & 3 & 8 & 7 & 2 & 2 & 7 & 1 & 1 & 4 & 5 \\
\hline
\end{tabular}

Figure 4. Distribution of conodont species and richness in LGA section from the Lower hermanni Zone to the Lower disparilis Zone. Bo (27, 28) indicates the position of the Boersma (1973) samples.

indicates that Bed $214 \mathrm{~b}$ is not younger than the hermanni Zone.

disparilis Zone (Figs 4, 5A). The record of Klapperina disparilis in Bed 214c identifies the base of the disparilis Zone. In the lower part of the zone, specimens of this taxon in several beds, and of $P$. dubius and $P$. cristatus cristatus, are common. In this part of the section is the lowest local (delayed) record of $P$. limitaris in the basal part of Bed 218. The entry of $P$. d. dengleri in the middle part of Bed 218 permits identification of the Upper disparilis Zone, and therefore the recognition of the twofold Lower and Upper subdivision of the disparilis Zone. In the upper part of Bed 218 is noteworthy the local entry of Schmidthognathus wittekindti. In the lower part of the overlying bed (219) the single occurrence of " $O$." s. proxima is registered. 


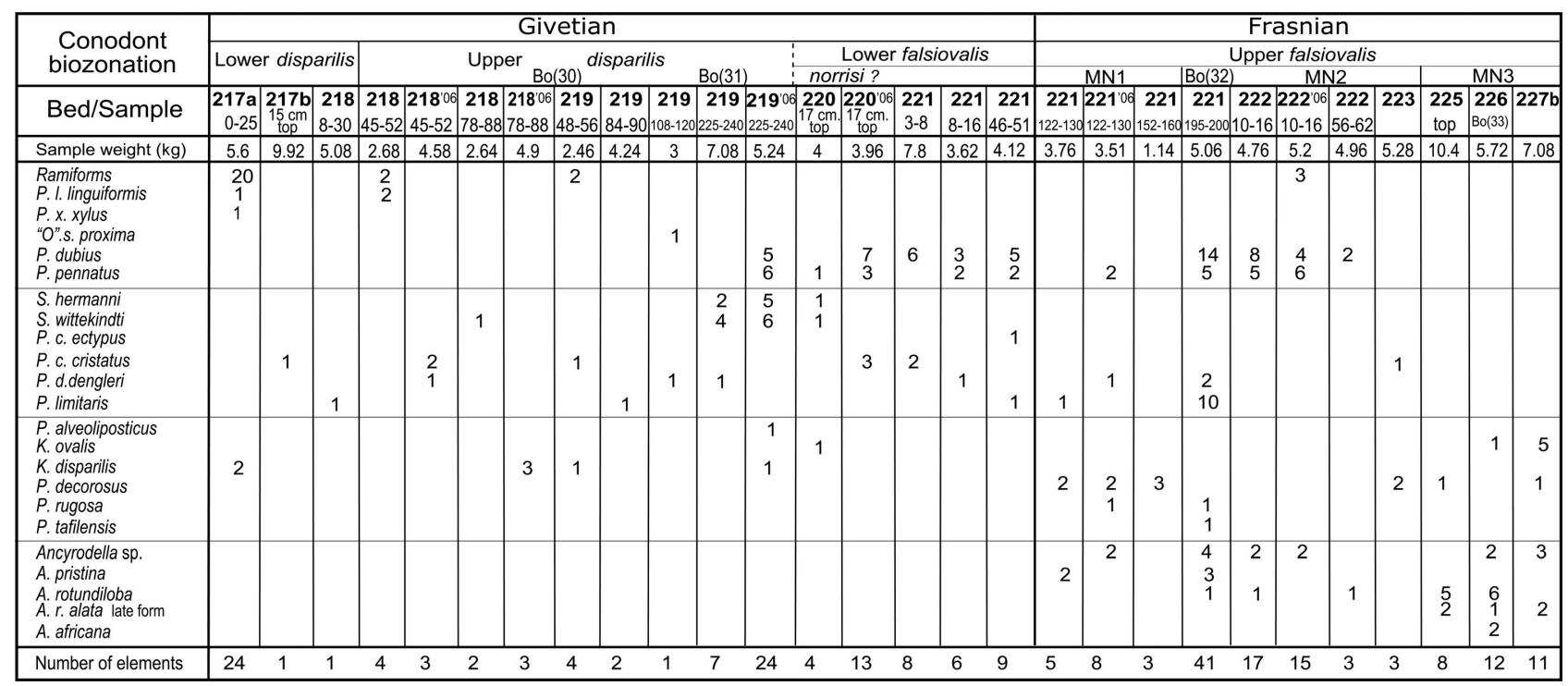

A

Figure 5. A - distribution of conodont species and richness in LGA section from the Lower disparilis Zone to the MN3. Bo $(30,31)$ indicates the position of the Boersma (1973) samples. - B - distribution of conodont species and richness in LGA-I section from the norrisi Zone to the MN Zone 3.

\begin{tabular}{|c|c|c|c|c|c|c|c|c|c|c|c|c|c|}
\hline \multirow{3}{*}{$\begin{array}{c}\text { Conodont } \\
\text { biozonation }\end{array}$} & \multirow{3}{*}{\multicolumn{2}{|c|}{$\begin{array}{r}\text { Giv. } \\
\text { Lw fals. } \\
\text { norrisi }\end{array}$}} & \multicolumn{11}{|c|}{ Lower Frasnian } \\
\hline & & & \multirow{2}{*}{\multicolumn{2}{|c|}{ MN1 }} & \multirow{2}{*}{\multicolumn{6}{|c|}{\begin{tabular}{l|l}
\multicolumn{2}{c}{ Upper falsiova } \\
MN2
\end{tabular}}} & \multirow{2}{*}{\multicolumn{3}{|c|}{ MN3 }} \\
\hline & & & & & & & & & & & & & \\
\hline Bed/Sample & $1 a$ & $\begin{array}{c}\mathbf{1 b} \\
72-84\end{array}$ & 1c & $1 c^{\prime} 06$ & 2 & 3 & 4 & 5 & $\begin{array}{l}\mathbf{6 a} \\
4-5 \\
\end{array}$ & \begin{tabular}{|c|}
$6 \mathbf{b}$ \\
$5-7 \mathrm{~cm}$ \\
top
\end{tabular} & nb'06 & $\begin{array}{c}7 \\
0-20 \\
\end{array}$ & $9 a$ \\
\hline Sample weight $(\mathrm{kg})$ & 4.8 & 4.56 & 2.3 & 5.34 & 2.7 & 5.66 & 2.7 & 2.7 & 5.02 & 6.5 & 3.1 & 3.43 & 4.75 \\
\hline Ramiforms & & & & 1 & & 2 & 2 & & & & & & \\
\hline P. dubius & 2 & 5 & 32 & 2 & 6 & 3 & 6 & 4 & 4 & & 2 & 3 & 5 \\
\hline $\begin{array}{l}\text { P. pennatus } \\
\text { P. d. dengleri } \\
\text { P. limitaris }\end{array}$ & 4 & $\begin{array}{l}4 \\
1\end{array}$ & 25 & 4 & 3 & 4 & 5 & $\begin{array}{l}5 \\
1\end{array}$ & $\begin{array}{l}4 \\
1\end{array}$ & 2 & & & 4 \\
\hline \begin{tabular}{|l|} 
P. collieri \\
Sk. norrisi \\
A. pristina \\
A. rotundiloba \\
A. r. alata late form \\
\end{tabular} & $\begin{array}{l}1 \\
1\end{array}$ & & 1 & & $\begin{array}{l}1 \\
2\end{array}$ & & & 1 & 1 & 1 & $\begin{array}{l}1 \\
1\end{array}$ & 1 & 1 \\
\hline Number of elements & 8 & 10 & 58 & 7 & 12 & 9 & 13 & 11 & 10 & 3 & 4 & 4 & 10 \\
\hline
\end{tabular}

norrisi Zone (Fig. 5A, B). The uppermost Givetian norrisi Zone cannot be definitively identified by means of the index taxon at the LGA section. However, the physical continuity of strata with the nearby LGA-I section, which contains Skeletognathus norrisi, permits tentative assignation of the lower part of Bed 221 (lower $51 \mathrm{~cm}$ of a $200 \mathrm{~cm}$ thick bed), and probably the upper half of Bed 220 (the upper $17 \mathrm{~cm}$ of a $42 \mathrm{~cm}$ thick bed) to the norrisi Zone.

The record of $P$. alveliposticus in the uppermost $15 \mathrm{~cm}$ of Bed 219 can either belong to the disparilis or to the norrisi Zone as proposed by Bardashev (1992). The record of $P$. d. dengleri in the middle part of Bed 218 indicates the Upper disparilis Zone, which also supports the extension of $P$. alveoliposticus higher than the Lower disparilis Zone, but whether or not the LGA record belongs to the Upper disparilis or to the norrisi Zone cannot be tested by means of critical conodonts.

Frasnian (Fig. 5A)

Lower Frasnian: MN1-MN3 zones (Fig. 5A). - The beginning of the Frasnian, and therefore of the Upper Devonian Series, is placed $122 \mathrm{~cm}$ above the base of Bed 221 with the lowest record of Ancyrodella pristina, corresponding to $\mathrm{MN}$ Zone 1. The sequential entries of Ancyrodella taxa permit recognition of the three lower zones (MN 1-MN 3) according to the Montaigne Noire zonation (Klapper 1989). MN Zone 2 starts $195 \mathrm{~cm}$ above the base of Bed 221 with the entry of $A$. rotundiloba. The entry of $A$. $r$. alata late form at the top of Bed 225 identifies the base of MN Zone 3. Within this zone is the entry of A. africana in Bed 226.

\section{LGA-I section}

The adjacent very short auxiliary section LGA-I $(220 \mathrm{~cm})$ was sampled in order to better characterize the Givetian/ Frasnian boundary. As this section shows some physical continuity with the LGA section, the projection of data would help in location of the G/F boundary in the LGA section.

\section{Uppermost Givetian: norrisi Zone (Fig. 5B)}

The lowest sample (1a) yielded Sk. norrisi together with $P$. pennatus that has narrow stratigraphical ranges around the G/F interval as well as $P$. dubius. The following sample 
(1b) yielded $P$. limitaris, a taxon that also has an upper range limited to the norrisi Zone or perhaps into the basal Frasnian.

\section{Lower Frasnian: MN1-MN3 zones (Fig. 5B)}

The Frasnian is identified in sample 1c by the presence of A. pristina; this sample belongs to MN Zone 1. MN Zone 2 starts in Bed 2, which yielded the entry of A. rotundiloba. The sequence of entries of the genus Ancyrodella continues with the record of $A$. r. alata late form in sample $6 \mathrm{~b}$, which indicates the beginning of MN Zone 3. This record matches the previous sequence described for LGA section, but the lithological correlation between both sections suggests that the taxon enters slightly earlier in LGA-I, as the Bed $6 \mathrm{~b}$ equivalent is placed below the top of Bed LGA 225.

\section{Comparison with Boersma's results}

In his pioneering work, Boersma (1973) studied with certain detail the section La Guardia d'Àres, a long section spanning from the Lower Devonian through the Lower Carboniferous; the interval between his samples 118 and 133 (Boersma 1973, fig. 8, table 2) largely corresponds with our LGA section. Boersma assigned the strata where samples 118-125 were taken to the Villech Fm.; however, we include these beds in the overlyig Comabella Fm., which is the equivalent of his Compte A Member (see Montesinos \& Sanz-López 1999, Valenzuela-Ríos \& Sanz-López 2002). Therefore, the boundary between the Villech and Comabella Fms is shifted down about $20 \mathrm{~m}$ according to thicknesses inferred from his lithological column (Boersma 1973, fig. 8). Many of his field numbers were recognised, and therefore a direct comparison with our results is possible. Boersma dated the interval we studied herein as Eifelian-upper Givetian and he recognized the following conodont zones established by Wittekindt (1965) in ascending order (table 2): Icriodus corniger (samples 118, 119), Spathognathodus bidentatus (120, 121), Polygnathus kockelianus (122-129), Ic. obliquimarginatus $(130,131)$ and Po. varcus (132-134). According to the leading zonation in Boersma's times, the three first zones comprised the whole Eifelian and the last two the Givetian (table 14).

The first of Boersma's numbered beds identified in the field was 119 that correspond with our Bed 172, which belongs to the upper Eifelian kockelianus or ensensis zones. Samples 120 and 121 would also fall within this interval. Our interpretation will place these samples slightly higher than the age attributed by Boersma, as he traced the base of the kockelianus Zone with his sample 122, which documents the lowest record of the taxon recorded by Boersma. Our yields lowered the lowest record of this taxon by about $1 \mathrm{~m}$. The next number recognized in the field was 124 , that corresponds to Bed 187 on the eastern limb of the fold. Boersma placed this sample in the kockelianus Zone, but our records indicate the hermanni Zone. This is a major discrepancy with his interpretations; the next record also reproduces this discrepancy. His number 125 corresponds to Bed 198 in the western limb of the fold. Sample 125 was also placed within the Eifelian kockelianus Zone; however, our records indicate the ansatus Zone for Bed 198. Number 126 was not identified, but numbers 127 and 128 were. Boersma placed these three samples within the Eifelian kockelianus Zone. Sample 127 corresponds to our Bed 204 and sample 128 to Bed 207; both beds are within the hermanni Zone. Sample 129 was not identified. Sample 130, the lowest sample considered by Boersma as Lower Givetian (Ic. obliquimarginatus Zone) corresponds to Bed 218, which is Upper disparilis Zone. Sample 131 was also assigned to the Ic. obliquimarginatus Zone; its corresponding bed in our section (Bed 219) is norrisi Zone. The last two Boersma samples recognized in our LGA section (132 and 133) were placed in the Givetian P. varcus Zone. Sample 132 correlates with our Bed 221, which is Lower Frasnian MN Zone 2; sample 133 correlates with Bed 226 that belongs to MN Zone 3.

\section{Summary}

The detailed sampling of La Guardia d'Àres sections yielded a conodont record of 47 taxa that encompasses a late Eifelian-Early Frasnian age for this part of the Comabella Formation, permitting the recognition of most of the Givetian and the lower three Frasnian zones. Furthermore, a direct comparison with the pioneer Boersma's sampling shows discrepancy with his interpretations.

The lowest biostratigraphical unit belongs to the Eifelian kockelianus Zone; its upper boundary (ensensis Zone) could not be identified. This lower part, termed kockelianus-ensensis, is represented in Beds 169-177. The base of the Givetian is correlated with a level situated between 20-33 cm above the base of Bed 178, which yielded the entry of I. obliquimarginatus. The delayed entry of the defining taxon, P. hemiansatus, is at the base of Bed 180. The sequence on the western limb of the fold comprises up to the Lower hermanni Zone, but only the ansatus Zone and the Lower hermanni Zone can be identified by means of conodonts. The conodont sequence on the eastern limb does not provide better information, as records are still puzzling and the Middle Givetian zones cannot be discriminated. The beginning of the hermanni Zone is identified in the uppermost $10 \mathrm{~cm}$ of Bed 200 (sample 200c) with the presence of $P$. limitaris; this zone extends to the Bed 214b. The base of the overlying disparilis Zone starts at Bed 214c with the entry of the defining taxon Klapperina disparilis. The entry of $P$. d. dengleri in the middle part of Bed 218 
allows recognition of the twofold subdivision (Lower and Upper) of the disparilis Zone. Basal beds (1a and 1b) of section LGA-I yielded Skeletognathus norrisi below the first Ancyrodella, characterizing the uppermost Givetian norrisi Zone. In section LGA, the physical continuity of strata combined with conodont yields pointed at a position of this zone between the upper half of Bed 220 and the lower part of Bed 221 (up to $51 \mathrm{~cm}$ above the base). The entry of A. pristina $122 \mathrm{~cm}$ above the base of Bed 221 (section LGA) and in Bed 1c (section LGA-I) indicates the beginning of the Frasnian; this taxon also serves to recognize MN Zone 1. The successive occurrences of $A$. rotundiloba and A. r. alata late form permit identification of MN2 and MN3 zones.

Direct comparison with Boersma's data allows some modifications of his interpretations. The most important are: 1) shifting downwards, by about $20 \mathrm{~m}$, the boundary between the Villech and Comabella Fms.; 2) including his samples 118-121 in the kockelianus Zone; 3) most of the samples he assigned to the kockelianus Zone (122-129) are of Middle or Upper Givetian age; 4) the samples 130 and 131 that were assigned by Boersma to the Lower Givetian (I. obliquimargiantus Zone) are placed in the Upper Givetian (Upper disparilis and norrisi zones); 5) the samples 132 and 133 that Boersma assigned to the varcus Zone, belong to the Frasnian MN2 and MN3 zones.

The record of $P$. tafilensis in the uppermost $5 \mathrm{~cm}$ of Bed 221 extends the stratigraphical range of the taxon to the MN2 Zone and represents the first record outside Morocco.

\section{Systematic palaeontology}

132 limestone conodont samples were collected (Figs 3-5); they were dissolved in dilute formic acid (6-8 \%). The insoluble residue was then, decanted and only a sieve of $1.25 \mathrm{~mm}$ was used to separate larger fragments from the finer fraction. The residue smaller than $1.25 \mathrm{~mm}$ was dried and hand-picked utilizing a microscope. Selected specimens were photographed with a Philips 30XL Scanning Electron Microscope; photographs were digitally produced and saved.

All specimens are deposited at the Museum of Geology, University of València MGUV. Only "Pa" and "I" elements are described.

\section{Genus Ancyrodella Ulrich \& Bassler, 1926}

\section{Ancyrodella pristina Khalymbadzha \& Chernysheva, 1970}

Figure 6A, B

2002 Ancyrodella pristina Khalymbadzha \& Chernysheva, 1970. - García-López \& Sanz-López, pl. 2, figs 21, 22 (renamed from the holotype of Ac. isabelae)
2007 Ancyrodella pristina Khalymbadzha \& Chernysheva, 1970. - Aboussalam \& Becker, p. 364, figs 9K, L, O, P.

2007 Ancyrodella rotundiloba binodosa Khalymbadzha \& Chernysheva, 1970. - Aboussalam \& Becker, fig. $9 \mathrm{M}, \mathrm{N}$.

2007 Ancyrodella rotundiloba Khalymbadzha \& Chernysheva, 1970. - Over, fig. 11.18.

2008 Ancyrodella pristina Khalymbadzha \& Chernysheva, 1970. - Liao \& Valenzuela-Ríos, pp. 2, 3 and 7; tab. $1 \mathrm{C}$; fig. $6 \mathrm{~J}$ (further synonymy).

2008 Ancyrodella binodosa Uyeno, 1967. - Ovnatanova \& Kononova, p. 1080, pl. 26, fig. 3.

2010 Ancyrodella pristina Khalymbadzha \& Chernysheva, 1970. - Gouwy, pp. 113, 114, pl. 10, figs 6a, b (see further synonymy).

Material. - Nine specimens from beds LGA22 $1_{122-130}(2)$, LGA22 $1_{195-200}(3)$, LGA-I/1c(1), LGA-I/2(1), LGA-I/5(1), LGA-I/6b ${ }^{06}(1)$. Figured specimens: LGA22 $1_{195-200}(2)$, MGUV6150-6151.

Description. - Pa element upper side: asymmetrical platform with triangular outline; acute, straight to sub-rounded lobes. Platform length equal or slightly longer than the blade. Anterior carina with 5-7 elliptic denticles, wide spaced and decreasing in size anteriorly. Slightly curved posterior carina, composed of 4-5 rounded to oval nodes, close spaced; some of them, fused. Posterior lobe ornamented by one row, one each side, of aligned nodes, which are sub-parallel to the carina and small nodes disposed close to the margins that are less numerous. Secondary lobes, with straight or rounded anterior margins; the outer is slightly asymmetrical. Pa element lower side: moderate basal pit, cross-shaped slightly stretched, located on the anterior part of the platform; it has projected flanges as in A. binodosa. Straight and narrow anterior keel and slightly bent posterior keel, which is wider (near to the pit) than the anterior one. Secondary keels poor to well developed, forming an angle close to $180^{\circ}$, that do not reach the ends of the lobe margins.

Remarks. - Traditionally, the species is considered as one of the early ancyrodellids forms. In the 1980's, Klapper (1985) named it as A. rotundiloba early form and, subsequently, Sandberg et al. (1989) re-used the name A. pristina, which previously was coined by Khalymbadzha \& Chernysheva (1970). Both concepts are used herein. The main characteristics of $A$. pristina are: 1) a lanceolate to sub-triangular platform-outline with rounded or straight anterior margins; 2) a simple ornamentation consisting of two large nodes, one on each side of the carina and few small nodes in the margins; 3) a longer free blade and 4) medium size, "T" shaped, basal cavity. Sandberg et al. (1989: 211) distinguished three morphotypes on the bases of the lateral lobe margins shape. Our specimens show only two forms: M1 and M2. 
Both specimens illustrated here are considered as mature forms of A. pristina; but one of them (Fig. 6A) is characterized by having a sub-rectangular shaped basal cavity, somewhat stretched; the angle formed by the outer secondary and main carinae is approximately $110^{\circ}$.

Stratigraphical distribution. - A. pristina is restricted to the Lower falsiovalis Zone; in terms of the Montagne Noire conodont zonation (Klapper 1989), it ranges from MN 1 to MN 2 zones (Lower Frasnian).

\section{Ancyrodella rotundiloba alata Glenister \& Klapper 1966}

Figure 6C, D

*1966 Ancyrodella rotundiloba alata n. sp., Glenister \& Klapper, pp. 799, 800, pl. 85, figs 1-8; pl. 86, figs 1-4.

1968 Ancyrodella rotundiloba alata Glenister \& Klapper, 1966. - Pollock, p. 420, pl. 61, figs 2, 3.

1974 Ancyrodella rotundiloba alata Glenister \& Klapper, 1966. - Uyeno, p. 24, pl. 1, figs 3, 7.

1985 Ancyrodella alata Glenister \& Klapper, 1966. - Klapper, p. 27, pl. 4, figs 1-8; pl. 5, figs 1-16; pl. 6, figs 1-12; pl. 7, figs 1-11; pl. 8, fig. 8; text-fig. 3K, L, O-R.

1985 Ancyrodella alata Glenister \& Klapper, 1966. - Bardashev \& Ziegler, p. 76, pl. 2, fig. 27.

1986 Ancyrodella alata Glenister \& Klapper, 1966. - Bultynck, pp. 276, 277, pl. 1, figs 10, 11.

1989 Ancyrodella rotundiloba rotundiloba (Bryant, 1921). - Ji, p. 316, pl. 3, figs 10-13.

1989 Ancyrodella alata Glenister \& Klapper, 1966. - Sandberg et al., p. 222, pl. 2, figs 7, 8; pp. 226, pl. 4, figs 8 , $10,11$.

1989 Ancyrodella alata Glenister \& Klapper, 1966. - Vandelaer et al., p. 239, pl. 1, figs 2a, b.

1991 Ancyrodella alata Glenister \& Klapper, 1966. Uyeno, p. 158, pl. 4, figs 4-6.

1992 Ancyrodella alata Glenister \& Klapper, 1966. - Bardashev, pp. 82, 83, pl. 11, figs 33-36.

1993 Ancyrodella alata Glenister \& Klapper, 1966. Racki \& Bultynck, pl. 9, figs 1-4.

1994 Ancyrodella alata Glenister \& Klapper, 1966. - Bai et al., 161, pl. 2, figs 1-3.

1994 Ancyrodella alata Glenister \& Klapper, 1966. - Weary \& Harris, p. 224, pl. 2, figs 11-14.

1995 Ancyrodella alata Glenister \& Klapper, 1966. - Hüneke, p. 124, pl. 2, fig. 9.

2003 Ancyrodella alata Glenister \& Klapper, 1966. - Over et al., p. 222, pl. 1, figs 16, 17.

2007 Ancyrodella alata Glenister \& Klapper, 1966. - Over, figs 11.15-17.

2008 Ancyrodella alata Glenister \& Klapper, 1966. - Ovnatanova \& Kononova, pp. 1079, 1080, pl. 26, figs 4, 5.
Material. - Eight specimens from beds LGA225top(2), LGA226(1), LGA227b(4), LGA-I/6(1). Figured specimens: LGA225top(2), MGUV6152-6153.

Description. - Pa element upper side: Slightly asymmetrical, alate platform outline. Rounded to straight lobes. Platform length half to two thirds of blade length. Slightly inclined anterior carina, composed of 6-7 oval to rounded denticles, which are partly fused at their bases, free tips, and connected by a weak ridge; straight posterior carina with 4-6 oval to rounded nodes, partly fused or single, and wide spaced; the carina decreases in size posteriorly. Secondary carina with 2-4 rounded nodes, separated or partly fused, decreasing in size to the margins. Outer secondary carina longer than inner. Platform ornamented by 2 or 3 rows of rounded nodes, decreasing in size to the margins and running sub-parallel to the carina. Pa element lower side: medium size, rhombic basal pit; anterior keel slightly bent and posterior straight. Fine secondary keels moderately well developed, ending before the crimp. Inner keel, curved anteriorly; outer, straight laterally to slightly curved posteriorly. Anterior and inner keels form an acute angle; secondary keels angle, about 100 to $120^{\circ}$.

Remarks. - A. rotundiloba alata is characterized by a strongly alate platform outline and by the typical development of secondary keels, where the inner keel is lateral-anteriorly directed, but the outer one is laterally or latero-posteriorly directed. The figured specimens (Fig. 6C, D) show typical features of this species, fine and well developed secondary keels with straight and asymmetrical anterior margins, and the high number of nodes. The presence of relatively numerous nodes, small basal pit, and non-cruciform aspect of our specimen suggest close relation to the "stratigraphically higher forms" of the Montagne Noire (see Klapper 1985, p. 27). All our specimens belong to Klapper's late form. The specimens figured by Uyeno (1974, pl. 1, figs 3, 7; 1991, pl. 4, fig. 4) show a shorter development of the keels, specially the outer one that does not reach beyond the middle of the lobe. Also these Canadian specimens have comparatively larger secondary lobes with more marked "alate" development.

Stratigraphical distribution. - This species ranges from the falsiovalis to the transitans zones (Sandberg et al. 1989). In terms of MN zones, this taxon ranges from MN 2 to MN 4 zones.

\section{Ancyrodella rotundiloba rotundiloba (Bryant, 1921) Figures 6E, F}

1921 Polygnathus rotundilobus sp. nov. Bryant, pp. 26, 27, pl. 12, figs 1-6.

1986 Ancyrodella rotundiloba (Bryant, 1921). - García- 
López, pp. 64, 65, pl. 1, figs 6-10; fig-text. 11 (includes synonymy).

1989 Ancyrodella rotundiloba (Bryant, 1921). - Sandberg et al., pp. 212, 213, pl. 2, figs 5, 6, 9, 10; pl. 3, figs 1-9; text-fig. 2, figs 8-10 (further synonymy).

1993 Ancyrodella rotundiloba (Bryant, 1921). - Ji \& Ziegler, p. 54 , pl. 1 , fig. 4 , text-fig. 7 , fig. 8 ; text-fig. 8 , fig. 2.

1994 Ancyrodella rotundiloba (Bryant, 1921). - Weary \& Harris, pl. 2, figs 7, 8, 15-21; text-figs 5-8.

1994 Ancyrodella rotundiloba late form (Bryant, 1921). Kirchgasser, pl. 2, figs L, M, Q, R.

1994 Ancyrodella rotundiloba early form (Bryant, 1921).Kirchgasser, pl. 2, figs $\mathrm{G}, \mathrm{H}$.

1995 Ancyrodella rotundiloba (Bryant, 1921). - Hünecke, pl. 2, figs 7,8 .

2004 Ancyrodella rotundiloba (Bryant, 1921). - Izokh et al., pl. 2, figs 4, 5 .

2008 Ancyrodella rotundiloba (Bryant, 1921). - Liao \& Valenzuela-Ríos, p. 7, figs 6Q, R.

2008 Ancyrodella soluta Sandberg et al., 1989. - Liao \& Valenzuela-Ríos, p. 7, figs 6K-P.

2010 Ancyrodella soluta Sandberg et al., 1989. - Gouwy, p. 114, pl. 10, figs 5a, b and 9a, b.

Material. - $19 \mathrm{~Pa}$ elements from Beds LGA221 ${ }_{195-200}(1)$, LGA222 ${ }_{56-62}(1), \quad$ LGA222 $_{10-16}(1), \quad$ LGA225top(5), LGA226(6), LGA-I/2(2), LGA-I/6b ${ }^{06}(1)$, LGA-I/7(1), LGA-I/9a(1). Figured specimens: LGA221 195-200, MGUV6154 and LGA222 ${ }_{10-16}$, MGUV6155.

Description. - Pa element upper side: symmetrical platform with sub-triangular outline, and rounded or slightly straight lobes. Platform slightly longer than blade. Ornamentation gap between blade and carina. Slightly bent to straight anterior carina, composed of 5-8 elliptic denticles, laterally compressed and increasing in height anteriorly; straight posterior carina with 6-9 oval to rounded nodes, individualized and close spaced that decrease in size posteriorly. Secondary carinae bear 2-4 elliptic to oval nodes, partly fused, and decreasing in size to the margins. Platform ornamentation consists of isolated to partly fused nodes, which are radially arranged from an intersection point between the secondary and main carinae. Pa element lower side: rhombic basal pit of moderate size. Slightly bent anterior keel and straight posterior; secondary keels incipiently to well developed; inner keel anteriorly or laterally curved; outer keel laterally directed or slightly curved posteriorly. The angle formed between inner and anterior keels is more than $60^{\circ}$; incipient secondary keels angle between $150-180^{\circ}$.

Remarks. - The presence of an ornamentation gap between the blade and the carina is a typical feature of $A$. rotundiloba, A. rugosa and A. r. alata "early" form.
The secondary keels of $A$. rugosa are more anteriorly directed, forming an angle of about $100-120^{\circ}$ and the platform bears more nodes.

The sub-triangular platform outline and the incipient development (or even lacking) of secondary keels in A. rotundiloba contrast with alate platform and clear secondary keels of $A$. r. alata.

The high number of nodes on the platform of the partly broken specimen (Fig. 6E) resembles A. rugosa. However, because of the poor development of the anteriorly directed inner- and laterally directed outer secondary keels, this specimen is included in A. rotundiloba "late" form. The rest of specimens from LGA can clearly be classified as A. rotundiloba "late" form.

Stratigraphical distribution. - From the beginning of the Middle falsiovalis Zone into the punctata Zone (Ji \& Ziegler 1993). In our material An. rotundiloba ranges from the base of MN Zone 2 to the lower half of MN Zone 3.

\section{Genus Icriodus Branson \& Mehl, 1938}

\section{Icriodus struvei Weddige, 1977}

Figure 6G

1977 Icriodus struvei Weddige sp. nov., pp. 296, 297, pl. 2, figs $21,22$.

1995 Icriodus struvei Weddige, 1977. - Sanz-López, p. 442 , pl. 23 , figs 12 , 13; pl. 25, figs 7-10.

2002 Icriodus struvei Weddige, 1977. - García-López \& Sanz-López, p. 172, pl. 1, figs 4, 17.

2010 Icriodus struvei Weddige, 1977. - Gouwy, pp. 118, 119, pl. 4, fig. 11.

2011 Icriodus struvei Weddige, 1977. - Walliser \& Bultynck, p. 17, pl. 4, figs 9, 10.

Material. - Two specimen from bed LGA178b $\mathrm{b}_{33-47}$; figured specimen MGUV6156.

Description. - "I" element upper side: slightly biconvex, tear-shaped spindle, with narrow margins anteriorly and wide posteriorly. Straight to curved middle row consisting of 9-10 elliptic to rounded denticles of different sizes and connected by a weak longitudinal ridge; the two more anterior denticles are higher and partly fused at the base, and their free tips are either rounded or sharp. The two more posterior middle rows denticles increase slightly in size with reclined cusp and convex posterior margin. Lateral rows consists of 6-7 denticles; last row denticles connected by a weak transversal ridge; denticles of the two anterior lateral rows are slightly posterior to corresponding middle row denticles. Two anterior transversal rows more spaced than 
posterior ones. I element lateral side: both ends of the unit higher than the central part. Middle row higher than lateral rows. I element lower side: symmetrical basal cavity, narrow at the anterior half and wide posteriorly. Rounded and broad posterior margin.

Remarks. - The spindle of I. struvei, I. obliquimarginatus and I. difficilis are slightly tear shaped; the lower number of denticles on the posterior middle row and the absence of the inner spur distinguish I. struvei from the other two.

Stratigraphical distribution. - According to Weddige (1977, p. 297), this species ranges from the middle part of the costatus Zone through the lower half of the ensensis Zone. Other authors, Belka et al. (1997), Mawson \& Talent (1989), extend the lower range to the base of the costatus Zone, and Bultynck (2003, p. 297) extends the range up to the base of the hemiansatus Zone. According to Gouwy \& Bultynck (2003, p. 327), the range of I. struvei starts in the upper part of the partitus Zone and reaches the base of the ensensis Zone.

The specimens from Bed LGA178b $b_{33-47}$ belong to the uppermost Eifelian.

\section{Genus Klapperina Lane, Müller \& Ziegler, 1979}

\section{Klapperina disparilis (Ziegler \& Klapper, 1976)} Figure 6H, I

1976 Palmatolepis disparilis n. sp. Ziegler \& Klapper, p. 119, pl. 1, figs 18-22, 24-31.

1980 Palmatolepis disparilis Ziegler \& Klapper, 1976. Johnson et al., pp. 100, 101, pl. 3, fig. 40.

1984 Palmatolepis disparilis Ziegler \& Klapper, 1976. Kim et al., pl. 24, figs 5, 6.

1985 Palmatolepis disparilis Ziegler \& Klapper, 1976. Ziegler \& Wang, p. 20, tab. 1, pl. 2, fig. 20; pl. 3, figs $1,3,4$.

1989 Klapperina disparilis (Ziegler \& Klapper, 1976). Wang, p. 73, pl. 37, fig. 4.

1992 Klapperina disparilis (Ziegler \& Klapper, 1976). Bardashev, pl. 7, figs 5, 7-10, 12-14, 19, 21.

1992 Klapperina disparilis (Ziegler \& Klapper, 1976). - Ji et al., p. 102, pl. 3, figs 15, 16 .

1993 Klapperina disparilis (Ziegler \& Klapper, 1976). Racki \& Bultynck, pl. 6, figs 6a, b.

1994 Klapperina disparilis (Ziegler \& Klapper, 1976). Bai et al., p. 166, pl. 25, figs 3-7.

1995 Klapperina disparilis (Ziegler \& Klapper, 1976). Sanz-López, p. 519, pl. 31, figs 14, 15.

1999 Klapperina disparilis (Ziegler \& Klapper, 1976). Lazreq, p. 66, pl. 2, figs 6, 7, 10, 11.
2007 Klapperina disparilis (Ziegler \& Klapper, 1976). Over, p. 1197, figs 3, $11.14 \& 11.15$.

2008 Klapperina disparilis (Ziegler \& Klapper, 1976). Liao \& Valenzuela-Ríos, p. 8, figs 5K, L, Q, R.

2010 Klapperina disparilis (Ziegler \& Klapper, 1976). Gouwy, pp. 120, 121, pl. 9, figs 7a, b (see further synonymy).

Material. - 13 specimens from beds LGA214c(3),

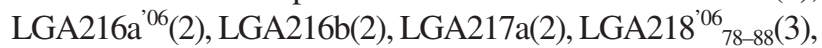
LGA219 ${ }_{48-56}(1)$ and LGA219'06 ${ }_{225-240}(1)$. Figured specimens: LGA218'06 ${ }_{78-88}(1), \quad$ MGUV6157 and LGA219 ${ }_{48-56}(1)$, MGUV 6158.

Description. - Pa element upper side: asymmetrical, ovalshaped platform with rounded anterior and sharp posterior margins. Maximum width between the end of the first third and the anterior half. Blade/platform ratio $1: 5$. Short free blade, consists of 3-4 oval denticles of similar height, partly fused at the bases and free at the tips. Carina straight anteriorly and slightly curved posteriorly, bears 7-10 oval to rounded denticles, partly fused (most anterior) and increasing in size posteriorly. Common ornamentation consists of transversal rows of fine nodes; some specimens with wider platform develop elongated nodes at the margins. Outer platform wider than inner. Shallow and wide anterior throughs. Pa element lateral side: most of the flat specimens show a high carina and a free blade. A few specimens exhibit slightly higher platform margins. $\mathrm{Pa}$ element lower side: medium size, L-shaped basal pit located near the mid point. Outer flange more developed than inner. Anterior keel, narrow close to the basal pit, but wides anteriorly; posterior keel wide near the basal pit that narrows posteriorly.

Remarks. - Both figured specimens are broken (Fig. 6H, I); however, the combination of an ornamentation pattern consisting of random arrangement of the fine nodes in the central part and coarser nodes in the anterior margins, a slightly curved carina with an increasing denticles size and a distinctive L-shaped basal cavity permits assigniment to K. disparilis.

Klapperina disparilis has a poor development of the platform lobe and fine nodes on the upper side in contrast with that of $K$. disparalvea, which is characterized by greater platform development and coarser nodes; furthermore, the outer flange of $\mathrm{Kl}$. disparalvea is considerably larger.

Stratigraphical distribution. - According to Ziegler \& Wang (1985) the highest range of this species reaches to the norrisi Zone, but Wang (1994) expands its range up to the lower half of the transitans Zone. Our specimens range from the base of the disparilis Zone to the top of the Upper disparilis Zone. 


\section{Klapperina ovalis (Ziegler \& Klapper, 1964) Figure 6J}

1957 Polygnathus dubia dubia sensu Bischoff \& Ziegler, pl. 1, figs 1, 2 .

1981 Polygnathus asymmetricus ovalis Ziegler \& Klapper, 1964. - Huddle, p. B26, pl. 7, figs 23-26; pl. 8, figs 10, 13; pl. 16, figs 23-25.

1985 Polygnathus asymmetricus ovalis Ziegler \& Klapper, 1964. - Ziegler \& Wang, p. 20, table 1, pl. 3, fig. 6.

1986 Polygnathus asymmetricus ovalis Ziegler \& Klapper, 1964. - Hou et al., pp. 40, 41, pl. 8, figs 1-3, 8-12.

1989 Polygnathus asymmetricus ovalis Ziegler \& Klapper, 1964. - Wang, p. 103, pl. 37, figs 5-7.

1991 Mesotaxis asymmetricus (Bischoff \& Ziegler, 1957). - Ovnatonova \& Kuzmin, pl. 1, figs 6a, b.

1992 Klapperina ovalis (Ziegler \& Klapper, 1964). - Bardashev, p. 74, pl. 7, figs 15, 17, 18, 20, 22, 23, 29, 30, 31,35 ; pl. 10, figs 21, 24-26.

1992 Klapperina ovalis (Ziegler \& Klapper, 1964). - Ji et al., p. 102, pl. 3, figs 17, 18 .

1994 Klapperina ovalis (Ziegler \& Klapper, 1964). - Bai et al., p. 166, pl. 25, figs 9-11.

2001 Klapperina ovalis (Ziegler \& Klapper, 1964). - Liao et al., p. 42, pl. 4, figs 27, 28 (see further synonymy).

2004 Mesotaxis falsiovalis Sandberg et al., 1989. - Izokh et al., p. 94, text-fig. 3; pl. 1, fig. 2.

2008 Klapperina ovalis (Ziegler \& Klapper, 1964). - Liao \& Valenzuela-Ríos, p. 6, tab. 1C, fig. 5S.

2008 Klapperina ovalis (Ziegler \& Klapper, 1964). - Ovnatonova \& Kononova, pp. 1082, 1083, pl. 25, figs 2,3 .

Material. - Seven specimens from beds LGA220 $17 \mathrm{~cm}$ sup $(1)$, LGA226(1) and LGA227b(5). Figured specimen: LGA226, MGUV6159.

Description. - Pa element upper side: symmetrical to slightly asymmetrical platform, oval to leaf shape with rounded to sharp anterior margins. Maximum width located between the end of the first third and the anterior half. Pointed posterior end. Blade/platform ratio $1: 5$. Short free blade, consists of 3 oval denticles, partly fused at their bases, the two anterior denticles are higher. Carina is slightly bent at the anterior and straight at the posterior end; composed of 7-10 oval denticles, partly fused (most anterior) at their bases, sharp free tips; their size and spacing increase posteriorly. Platform ornamented by transversal rows or irregular arrangement of fine nodes, which can cover total or partly the oral surface; some specimens show fused nodes at the platform margins. Shallow and wide anterior throughs. Pa element lateral side: all specimens are flat and downwards arched; high free blade. Pa element lower side: slightly asymmetrical, medium size, oval to tear shaped basal pit, located between near the end of the first anterior third and the anterior half. Outer flange more developed than inner. Slightly bent and narrow anterior keel; wide posterior keel near to the pit that narrows posteriorly.

Remarks. - The oval outline, the distribution of fine nodes in the external part, and symmetrical basal pit near the half length of the platform are typical characteristics of K. ovalis.

The broken specimen (Fig. 6J) has a short free blade, a straight carina that reaches the posterior end, and well developed keels; the unit is slightly arched in lateral view.

$K$. ovalis has a smaller basal pit and more symmetrical labial expansions than $K$. unilabius.

In contrast with $M$. falsiovalis, the basal pit of $K$. ovalis is located in a more posterior position.

Our material is closer to the North-African and European forms and differ clearly from Asiatic specimens, which have a markedly larger basal cavity.

Stratigraphical distribution. - According to Ziegler \& Sandberg (1990), K. ovalis appears in the disparilis Zone and extends to the hassi Zone.

\section{Genus Ozarkodina Branson \& Mehl, 1934}

We use the concept of Ozarkodina according to the restricted sense of Murphy et al. 2004; in order to avoid creation of new genera at this state of knowledge, we use quotation marks for the specimens referred herein to Ozarkodina to stress that they are not true Ozarkodina and that in future works new genera will have to be established for them.

\section{“Ozarkodina” sannemanni adventa (Pollock, 1968)} Figure 6K

1968 Spathognathodus sannemanni adventa $\mathrm{n}$. subsp.; Pollock, p. 439, pl. 63, figs 22, 24, 25.

1985 Ozarkodina aff. proxima (Pollock, 1968). - Ziegler \& Wang, pl. 2, fig. 2.

?1992 Ozarkodina sannemanni adventa (Pollock, 1968). Bardashev, p. 68, pl. 4, fig. 40.

2007 Oz. sannemanni adventa (Pollock, 1968). - Aboussalam \& Becker, pp. 349-352, 354, tables 1-5, fig. 8R.

Material. - Two specimens from beds LGA201 $15 \mathrm{~cm}$ inf. and LGA189top. Figured specimen: LGA189top, MGUV6160.

Description. - Pa element upper side: elongated and laterally compressed unit. Anterior blade higher than posterior. Only the outer platform is developed. Carina straight or slightly bent to the anterior and slightly bent posteriorly; it consists of 15-16 rounded to oval denticles, fused at their 

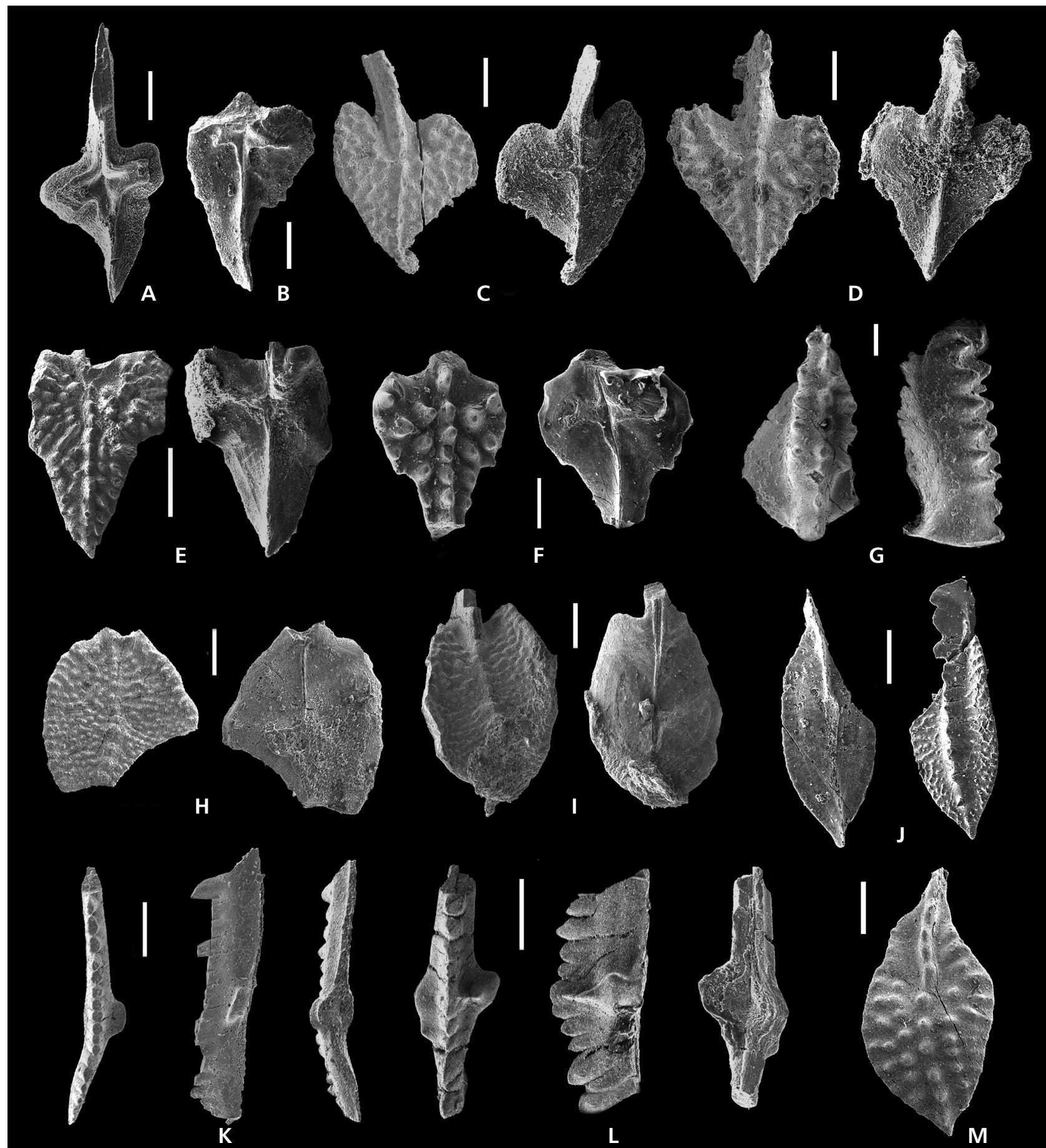

Figure 6. All scale bars are $200 \mu \mathrm{m}$, except G, L $(=100 \mu \mathrm{m})$ and E $(=500 \mu \mathrm{m})$. A, B - Ancyrodella pristina Khalymbadzha \& Chernysheva, 1970. A - lower view of MGUV6150; B - lower view of MGUV6151; both specimens from Bed LGA 221 195-200, MN Zone 2. $\bullet$ C, D - Ancyrodella rotundiloba alata Glenister \& Klapper, 1966. C - lower and upper views of MGUV6152; D - upper and lower views of MGUV6153; both specimens from Bed LGA 225top, MN Zone 3. E, F - Ancyrodella rotundiloba rotundiloba (Bryant, 1921). E - upper and lower views of MGUV6154, Bed LGA221 $1_{195-200}$, MN Zone 2; upper and lower views of MGUV6155, Bed LGA 222 ${ }_{10-16}$, MN Zone 2. • G - Icriodus struvei Weddige, 1977. Upper and lateral views of MGUV6156, Bed LGA 178b $\mathrm{b}_{33-47}$, kockelianus-ensensis Zone. • H, I - Klapperina disparilis (Ziegler \& Klapper, 1976). H - upper and lower views of MGUV6157, Bed LGA 21878-88, Upper disparilis Zone; I - upper and lower views of MGUV6158, Bed LGA 21948-56, Upper disparilis Zone. -J - Klapperina ovalis (Ziegler \& Klapper, 1964). Lower and upper views of MGUV6159, Bed LGA 226, MN Zone 3. • K - "Ozarkodina" sannemanni adventa (Pollock, 1968). Upper, lateral and lower views of MGUV6160, Bed LGA 189top, Lower hermanni Zone. • L - "Ozarkodina" sannemanni proxima (Pollock, 1968). Upper, lateral and lower views of MGUV6161, Bed LGA 219 108-120, Upper disparilis Zone. • M - Polygnathus alveoliposticus Orr \& Klapper, 1968. Upper view of MGUV6162, Bed LGA219'06 ${ }^{225-240}$, Upper disparilis Zone. 
bases and sharp or partly fragment at their tips. The most anterior three to four denticles are slightly larger than the posterior ones. Outer platform lobe has an ear-shaped outline. Pa element lateral side: palisade denticles decrease in size posteriorly. Pa element lower side: asymmetrical basal cavity, with only one incipient lateral expansion. Open, wide and deep grooves, parallel-sided that narrow to both ends.

Remarks. - "Ozarkodina" sannemanni adventa is characterised by a lateral incipient lobe on one or both sides with sub-rounded and symmetrical outline, and an anterior or posterior inflexion.

Our specimens develop only an outer lateral lobe without denticles as in Fig. 6K, but specimens from Morocco may have two symmetrical lateral lobes.

Stratigraphical distribution. - According to Bardashev (1992), the first occurrence of this subspecies is within the disparilis Zone and ranges to the basal Frasnian; but Aboussalam \& Becker (2007) extend the range from the base of the hermanni to MN Zone 2 Zone; Narkiewicz \& Bultynck (2010), extended the range up to the punctata Zone (which corresponds to MN Zone 5).

\section{“Ozarkodina” sannemanni proxima (Pollock, 1968)}

Figure 6L

1968 Spathognathodus sannemanni proximus n. subsp.; Pollock, pp. 439-440, pl. 63, figs 8, 9, 12, 13, 18, 19.

1992 Ozarkodina sannemanni proxima (Pollock, 1968). Bardashev, p. 68, pl. 4, figs 41, 42.

2003 Ozarkodina sannemanni proxima (Pollock, 1968). Aboussalam, p. 173, pl. 24, figs 11, 12.

2007 Ozarkodina sannemanni proxima (Pollock, 1968). Aboussalam \& Becker, tables 1, 2, 4, 5; figs 8P, Q.

2010 "Ozarkodina" sannemanni proxima (Pollock, 1968). - Gouwy, p. 125, pl. 9, fig. 4.

Material. - Only one specimen from sample LGA219 ${ }_{108-120}$, MGUV6161.

Description. - Pa element upper side: elongated and laterally compressed unit. Straight blade with two lateral asymmetrical platform lobes. The carina consists of at least 10 rounded to oval denticles of irregular size, fused only at the bases; sharp free tips. Sub-trapezoidal shaped outer platform lobe with two nodes of different size, the outer larger. Rounded, smooth inner platform lobe, narrower but longer than outer; posterior lobe margin reaches further than the outer one. Pa element lateral side: high blade of irregular, palisade big denticles. Conspicuous cusp, but not the highest denticle. The second to last denticle seems to be the highest, most of posterior denticles are reclined. Subtle ledge at the base of anterior denticles. Pa element lower side: asymmetrical and deep excavated basal cavity. Wide, parallel-sided anterior groove and narrow posterior.

Remarks. - The different development of the lateral lobes and the presence of at least one denticle on the outer lobe are diagnostic characteristics to distinguish "O." sannemannni proxima from others subespecies.

Stratigraphical distribution. - According to Pollock (1968), this subspecies ranges from the hermanni to the transitans zones.

\section{Genus Polygnathus Hinde, 1879}

\section{Polygnathus alveoliposticus Orr \& Klapper, 1968 Figure 6M}

1968 Polygnathus alveoliposticus n. sp. Orr \& Klapper, pp. 1073, 1074, pl. 139, figs 10-18.

1971 Polygnathus alveoliposticus Orr \& Klapper, 1968. Orr, p. 46, pl. 4, figs 6-8.

1981 Polygnathus alveoliposticus Orr \& Klapper, 1968. Huddle, p. B25, pl. 6, figs 8-14; pl. 7, figs 9-10?.

?1982 Polygnathus alveoliposticus Orr \& Klapper, 1968. Klug, p. 16, pl. 1, figs 26-28.

1992 Polygnathus alveoliposticus Orr \& Klapper, 1968. Bardashev, p. 42, text-fig. 4, pl. 11, figs 27, 28.

2003 Polygnathus alveoliposticus Orr \& Klapper, 1968. Aboussalam, p. 175, pl. 16, figs 7, 8.

Material. - Only one specimen from sample LGA219 ${ }_{(225-240)}$, MGUV6162.

Description. - Pa element upper side: Oval shaped and slightly asymmetrical platform. Total length double the width. Free blade absent or very short. Sharp anterior and posterior ends. Anterior part of carina slightly sigmoidal consisting of five oval denticles, which are close spaced. Posterior part, carina slightly curved with seven rounded and wide spaced denticles. Platform covered by coarser and rounded nodes, which are mainly situated in the posterior half, and thinner and rounded nodes or short transversal ridges at the margins. Pa element lateral side: the unit is flat-convex. Pa element lower side: basal pit partly covered by matrix; approximately located at the middle half.

Remarks. - This species is characterised by its oval shaped outline, a very short free blade, a slightly curved carina and two longitudinal row of nodes, on each side, at the posterior part and transversal nodes situated at the inner and anterior part of the platform. The figured specimen (Fig. 6M) 
has a carina consisting of oval narrow denticles at the anterior part and rounded and spaced denticles at the posterior part; the platform of specimen MGUV6162 has fewer nodes than the holotype. The unit is slightly arched downwards.

The basal pit of M. falsiovalis is located more anteriorly (at the first third part of the unit); in comparison the nodes are larger and regularly arranged in P. alveoliposticus.

Stratigraphical distribution - According to Klug (1982), this species is recorded from the middle part of the ansatus Zone to the Lower disparilis Zone; but Bardashev (1992), extended its ranges up to the Lower falsiovalis Zone. Our specimen corresponds to the norrisi Zone.

\section{Polygnathus angusticostatus Wittekindt, 1966 Figure 7B}

*1966 Polygnathus angusticostata n. sp. Wittekindt, p. 631, pl. 1, figs 15-18.

1970 Polygnathus angusticostata Wittekindt, 1966. - Bultynck, p. 123, pl. 16, figs 1-3, 6 .

1981 Polygnathus angusticostatus Wittekindt, 1966. Sparling, pp. 309, 311, pl. 1, figs 13, 14-18, 21-23.

1982 Parapolygnathus angusticostatus Wittekindt, 1966.Uyeno et al., p. 30, pl. 1, figs 26-28, 35-41.

1983 Polygnathus angusticostatus Wittekindt, 1966. Sparling, p. 854, fig. $13 Z$.

1984 Polygnathus angusticostatus Wittekindt, 1966. Kim et al., pp. 75, 76, pl. 23, fig. 8.

1985 Polygnathus angusticostatus Wittekindt, 1966. - Ziegler \& Wang, p. 30, pl. 1, fig. 31.

1985 Polygnathus angusticostatus Wittekindt, 1966. Bultynck, p. 282, pl. 7, fig. 21.

1985 Polygnathus angusticostatus Wittekindt, 1966. Schönlaub, p. 361, pl. 5, figs 9, 10.

1990 Polygnathus angusticostatus Wittekindt, 1966. Lazreq, p. 68, pl. 2, figs 8, 9.

1990 Polygnathus angusticostatus Wittekindt, 1966. Bardashev, pp. 34, 35, pl. 5, figs 13, 14, 21, 24.

1992 Polygnathus angusticostatus Wittekindt, 1966. Bardashev, p. 39, tables 4.3, 5, 9, 10, pl. 2, figs 29, 31.

1995 Polygnathus angusticostatus Wittekindt, 1966. - SanzLópez, pp. 483, 484, pl. 21, figs 10, 11; pl. 24, fig. 3.

2003 Polygnathus angusticostatus Wittekindt, 1966. Benfrika \& Bultynck, p. 212, pl. 1, fig. 11.

2003 Polygnathus angusticostatus Wittekindt, 1966. Pyle et al., pp. 106, 107, tables 1, 2, pl. 2.

2004 Polygnathus angusticostatus Wittekindt, 1966. Gouwy, p. 90, pl. 3, fig. 7.

2010 Polygnathus angusticostatus Wittekindt, 1966. Gouwy, p. 133, pl. 4, figs 6, 7, 9 (further synonymy).

2011 Polygnathus angusticostatus Wittekindt, 1966. Walliser \& Bultynck, p. 13, pl. 2, figs 3, 4 .
Material. - Two specimens from Bed LGA178a(2). Figured specimen: MGUV6164.

Description. - Pa element upper side: oval to sub-triangular shield-shaped, symmetrical platform with rounded outline. Maximum width at the middle of the unit. Posterior end slightly sharp. Broken free blade. Straight carina with 8-10 rounded to oval denticles, decreasing in size to the posterior. The platform bears marginal nodes or short transversal ridge. Shallow and wide adcarinal troughs. $\mathrm{Pa}$ element lateral side: flat unit, downwards arched. Pa element lower side: Small oval-shaped basal pit located at the anterior part of the platform. Posterior keel straight.

Remarks. - The specimen MGUV6164 (Fig. 7B) is assigned to $P$. angusticostatus by the combination of short transversal ridges, shallow adcarinal troughs, a low carina and a small basal pit.

Polygnathus angusticostatus has shorter and marginal transversal ridges and shallower and wider adcarenal throughs than $P$. robusticostatus.

Polygnathus angustipennatus has a reduced platform, its maximum width is generally located at the anterior margin, long anterior blade and shorter posterior one, narrow and deep adcarinal throughs; high carina that decreases to the posterior and a large basal pit. All these characters permit distinction from the closely related species $P$. angusticostatus.

Stratigraphical distribution. - According to Walliser \& Bultynck (2011), P. angusticostatus ranges from the costatus Zone and reaches to the base of the hemiansatus Zone.

\section{Polygnathus angustipennatus Bischoff \& Ziegler, 1957} Figure 7A

*1957 Polygnathus angustipennata n. sp. Bischoff \& Ziegler, p. 85 , pl. 2, fig. 6; pl. 3, figs 1-3.

1966 Polygnathus angustipennata Bischoff \& Ziegler, 1957. - Wittekindt, p. 631, pl. 1, fig. 14.

1970 Polygnathus angustipennata Bischoff \& Ziegler, 1957. - Bultynck, p. 124, pl. 17, figs 3-6; pl. 18, fig. 1.

1971 Polygnathus angusticostatus Wittekindt, 1966. - Orr, p. 47, pl. 4, figs 12-17.

1980 Polygnathus angustipennatus Bischoff \& Ziegler, 1957. - Xiong, p. 89, pl. 27, figs 1-3.

1981 Polygnathus angustipennatus Bischoff \& Ziegler, 1957. - Sparling, pp. 311, 312, pl. 1, figs 10-12, 19, 20, 24.

1985 Polygnathus angustipennatus Bischoff \& Ziegler, 1957. - Schönlaub, p. 361, pl. 4, figs 21-25.

1989 Polygnathus angustipennatus Bischoff \& Ziegler, 1957. - Wang, pp. 101, 102, pl. 34, figs 3, 4.

1990 Polygnathus angustipennatus Bischoff \& Ziegler, 1957. - Lazreq, p. 68, pl. 2, figs 5-7. 
1992 Polygnathus angustipennatus Bischoff \& Ziegler, 1957. - Bardashev, pp. 36, 44, 46, 47, tables 4.1, 6, 7, 9, 10; pl. 2, figs 18-24.

1995 Polygnathus angustipennatus Bischoff \& Ziegler, 1957. - Sanz-López, p. 484, pl. 21, fig. 9.

2003 Polygnathus angustipennatus Bischoff \& Ziegler, 1957. - Benfrika \& Bultynck, p. 212, pl. 1, fig. 12.

2010 Polygnathus angustipennatus Bischoff \& Ziegler, 1957. - Gouwy, pp. 133, 134, pl. 4, figs 5, 8 (further synonymy).

2011 Polygnathus angustipennatus Bischoff \& Ziegler, 1957. - Walliser \& Bultynck, p. 13, pl. 2, figs 5a, b.

Material. - Nine Pa elements from beds LGA174 ${ }_{3-25}(1)$, LGA175 $_{13-15}(1), \quad$ LGA177 $_{18}$ cm inf.(1), LGA178a(2), LGA $179^{0^{\prime} 6}{ }_{12} \mathrm{~cm}$ inf.(3). Figured specimen LGA178a (1), MGUV6163.

Description. - Pa element upper side: oval to triangularshaped, symmetrical and short platform. In complete specimens the length ratio between free blade and platform plus posterior end is about $2: 5$. Straight anterior free blade; sharp and slightly curved posterior end. High anterior carina with 5 or 6 oval denticles. Low posterior carina with 9 rounded denticles. Deep adcarinal throughs and fine nodes alternate with short transversal ridges on the lateral margins. Pa element lateral side: flat unit slightly arched. Pa element lower side: large basal pit located at the first third of the platform. Deep, parallel-sided, narrow posterior basal groove.

Remarks. - The broken figured specimen (Fig. 7A) mainly preserves the posterior part of the platform with a high carina, a narrow and long posterior end, and marginal nodes and short transversal ridges.

Polygnathus angustipennatus shares with $P$. trigonicus a sub-triangular platform outline, but the former has a very narrow and short platform with a simple ornamentation; in contrast, the latter, has larger platform that bears a well developed ornamentation.

For a comparison with the closely similar $P$. angusticostatus, see under the latter.

Stratigraphical distribution. - According to Walliser \& Bultynck (2011), P. angustipennatus ranges from australis to ensensis zones.

\section{Polygnathus ansatus Ziegler \& Klapper, 1976 Figure 7C}

*1976 Polygnathus ansatus n. sp. Ziegler \& Klapper (in Ziegler et al.), pp. 119, 120, figs 11-26.

1983 Polygnathus ansatus Ziegler \& Klapper, 1976. Klapper \& Barrick, p. 1237, figs 12L, M, O, P, R-U.
1984 Polygnathus ansatus Ziegler \& Klapper, 1976. - Kim et al., pl. 24, fig. 4.

1986 Polygnathus ansatus Ziegler \& Klapper, 1976. García-López, p. 87, pl. 11, fig. 23; pl. 12, figs 1-13 (see further synonymy).

1988 Polygnathus ansatus Ziegler \& Klapper, 1976. Sparling, p. 15, fig. 18.12 .

1992 Polygnathus ansatus Ziegler \& Klapper, 1976. - Bardashev, text-figs 5.4, 5.5, 8, pl. 5, figs 23, 27.

1994 Polygnathus ansatus Ziegler \& Klapper, 1976. - Bai et al., p. 175, pl. 22, figs 11, 12.

1995 Polygnathus ansatus Ziegler \& Klapper, 1976. Sanz-López, pp. 484, 485, pl. 30, figs 8, 9.

1998 Polygnathus ansatus Ziegler \& Klapper, 1976. - Narkiewicz \& Narkiewicz, pl. 1, figs 3, 4.

1998 Polygnathus ansatus Ziegler \& Klapper, 1976. - Narkiewicz \& Narkiewicz, p. 216, table 1, pl. 1, figs 3,4 .

1999 Polygnathus ansatus Ziegler \& Klapper, 1976. - Lazreq, p. 75, pl. 1, fig. 17.

1999 Polygnathus ansatus Ziegler \& Klapper, 1976. Sparling, p. 899, figs 3.30-3.33.

2003 Polygnathus ansatus Ziegler \& Klapper, 1976. Aboussalam, p. 176, pl. 15, figs 1-6.

2008 Polygnathus ansatus Ziegler \& Klapper, 1976. - Liao \& Valenzuela-Ríos, p. 8, fig. 3K, L (with synonymy).

2010 Polygnathus ansatus Ziegler \& Klapper, 1976. - Narkiewicz \& Bultynck, table 2, 5, 6, figs 4A-E, G, K.

Material. - Two specimens from beds LGA189 ${ }_{15-16}$ and LGA197. The figured specimen belongs to Bed LGA197, MGUV6165.

Description. - Pa element upper side: asymmetrical and slender main body. Maximum width at the posterior half. Straight carina with 10-14 rounded and wide spaced denticles; they decrease in size to the posterior carina. The platform bears a few fine nodes. Anterior through margins outwards bowed, specially, the outer margin, which is more curved. Remarkable constriction at the anterior part of the platform. Geniculation points approximately opposite. Pa element lateral side: downwards arched unit. $\mathrm{Pa}$ element lower side: Basal cavity partially covered by matrix, but the specimen from bed LGA189 ${ }_{15-16}$ has a moderate size, symmetrical basal cavity. Deep, narrow parallel-sided posterior groove.

Remarks. - The figured specimen, Fig. 7C, shows the typical features of $P$. ansatus: marked constriction at the anterior platform, and well-developed anterior through margins.

Stratigraphical distribution. - According to Liao \& Valenzuela-Ríos (2008), Narkiewicz \& Bultynck (2008, 2010) and Aboussalam (2003), this species ranges from the base 
of the ansatus Zone to the Upper hermanni Zone; but Bardashev (1992) extends the upper range to the Lower disparilis Zone.

\section{Polygnathus oblongus Weddige, 1977 \\ Figure 7F, G}

*1977 Polygnathus costatus oblongus n. subsp. Weddige, pp. 309, 310, pl. 4, figs 71, 72.

1979 Polygnathus costatus oblongus Weddige, 1977. Lane et al., p. 218, pl. 1, fig. 16.

1980 Polygnathus costatus oblongus Weddige, 1977. Johnson et al., pl. 4, fig. 17.

1989 Polygnathus costatus oblongus Weddige, 1977. Wang, p. 106, pl. 31, figs 5, 6.

1990 Polygnathus costatus oblongus Weddige, 1977. Bardashev, p. 34, pl. 3, figs 18, 19, 25; pl. 11, fig. 19.

1992 Polygnathus costatus oblongus Weddige, 1977. Bardashev, p. 62, text-figs 7, 10, pl. 1, fig. 33.

Material. - Two specimens from bed LGA168. MGUV6166, 6167.

Description. - Pa element upper side: Sub-rectangular and elongate asymmetrical platform. The maximum width is approximately at the middle of the posterior part of the unit. Blade/platform ratio about $1: 5$. Anterior platform restricted by a "rostrum". Sub-rounded posterior margin of the platform, weakly or strongly bent to the inner side. Short and straight free blade, composed of 4-5, laterally compressed, oval denticles. Carina composed of 10-12 rounded denticles, partially fused at their bases; they decrease in size and wider their space posteriorly; it is straight anteriorly where narrows to a fine ridge; the posterior part is also straight at the beginning but bends posteriorly. The platform bears fine transversal ridges, which are replaced by simple fine nodes at both, anterior and inner posterior margins. Deep and slightly wide adcarinal throughs at the anterior part that shallow at the posterior part. Outer platform slightly wider than the inner. The outer anterior margin is lower than the inner. Pa element lateral side: slightly arched downwards. Pa element lower side: small basal pit located at the beginning of the anterior part of the platform. Straight, wide and deep anterior basal groove; bent posterior keel.

Remarks. - The figured specimen (Fig. 7F) has a moderate development of the outer platform and it has a lower outer anterior platform margin.

This species evolved from $P$. costatus by narrowing the anterior part of the platform and developing an inner-turn of the posterior platform.

Polygnathus oblongus differs from $P$. costatus by the development of a sinuous outer posterior platform.
Stratigraphical distribution. - According to Weddige (1977), P. c. oblongus is restricted to the kockelianus Zone; but Bardashev (1990, 1992), extends the range down to the australis Zone.

\section{Polygnathus cristatus cristatus Hinde, 1879 Figure 7D, E}

*1879 Polygnathus cristata n. sp. Hinde, p. 366, pl. 17, fig. 11.

1964 Polygnathus cristata Hinde, 1879. - Orr, p. 13, pl. 3, figs 4-8; text-figs 4A-K.

1966 Polygnathus cristata Hinde, 1879. - Flajs, pl. 23, fig. 8.

1985 Polygnathus cristatus Hinde, 1879. - Ziegler \& Wang, p. 36, pl. 2, figs 3, 4.

1985 Polygnathus cristatus Hinde, 1879. - Bardashev \& Ziegler, p. 76, pl. 2, figs 1, 3.

1989 Polygnathus cristatus Hinde, 1879. - Ji, p. 316, pl. 3, figs 22-25.

1992 Polygnathus cristatus Hinde, 1879. - Bardashev, p. 76, pl. 8, figs 17-21.

1994 Polygnathus cristatus Hinde, 1879. - Bai et al., pp. 176, 177, pl. 24, fig. 1.

1994 Polygnathus cristatus? Hinde, 1879. - Kirchgasser, p. 129, pl. 3, figs D, E, I, J.

1999 Polygnathus cristatus Hinde, 1879. - Lazreq, p. 86, pl. 2, figs 2, 3 .

2001 Polygnathus cristatus Hinde, 1879. - Liao et al., p. 23, pl. 4, figs 10, 13 (with synonymy).

2007 Polygnathus cristatus cristatus Hinde, 1879. Aboussalam \& Becker, p. 359, fig. $9 \mathrm{H}$.

2008 Polygnathus cristatus cristatus Hinde, 1879. - Liao $\&$ Valenzuela-Ríos, table $1 \mathrm{C}$, figs $5 \mathrm{M}, \mathrm{N}$.

2010 Polygnathus cristatus cristatus Hinde, 1879. Gouwy, pp. 139, 140, pl. 9, figs 8a, b.

Material. - 14 specimens from samples LGA214c ${ }^{\circ}(1)$, LGA216a(1), LGA216a '06(2), LGA217b(1), LGA218'06(2), LGA219 $48-56(1), \quad \operatorname{LGA}_{220}{ }^{06}(3), \operatorname{LGA}_{22} 1_{3-8} \mathrm{~cm}(2)$ and LGA223(1). Figured specimens: LGA216a ${ }^{\circ 6}$, MGUV6168 and LGA219 ${ }_{48-56}$, MGUV6169.

Description. - Pa element upper side: oval shaped and slightly asymmetrical platform, which widest part is at the anterior half. Blade/platform ratio about $1: 5$. Rounded or sharp posterior end. In complete specimens, the free blade is short and consists of 5-8 oval denticles; in some specimens the two anterior denticles are higher. Carina with 9-16 aligned, rounded denticles, of comparable size and height, slightly lower than denticles on the blade; posteriorly they are smaller and more elliptical; in the anterior third they are close spaced and, in some specimens, fused 
in a ridge; in the posterior part they are widely spaced. The platform has 2-3 rows of rounded nodes of variable size, arranged oblique in the anterior part and sub-parallel to the carina posteriorly. The anterior nodes are larger than the posterior ones. Rounded and smooth anterior platform margins. Incipient development of the anterior adcarinal through. Pa element lateral side: anterior part of the unit, slightly arched downwards. Pa element lower side: Small and asymmetrical basal pit, located anterior of the platform mid-length; it continues anteriorly and posteriorly with straight, narrow keels.

Remarks. - The partially matrix-covered, broken specimen (Fig. 7E) shows the typical nodes arrangement and the asymmetrical basal pit. The "puzzle" specimen (Fig. 7D) shows a slightly sinuous carina with denticle-size decreasing posteriorly and the platform bears simple longitudinal rows of nodes, which are sub-parallel to the carina.

Polygnathus $c$. cristatus is similar to $M$. falsiovalis in the oval platform outline, location and size of the basal pit, but the former has a higher number of coarser nodes, which are arranged in longitudinal rows, while the platform of the latter is ornamented by fine nodes that have a transverse arrangement. Additionally, the asymmetrical basal pit of $P$. c. cristatus is larger and located more posteriorly.

The differences between $P$. c. cristatus and P. c. ectypus are described below.

Stratigraphical distribution. - According to Klapper \& Ziegler (1977), P. c. cristatus ranges from the Upper hermanni Zone to the punctata Zone; but Klapper \& Johnson (1990) indicate the last occurrence of this subspecies in the Lower disparilis Zone.

Our specimens range from the base of the Lower disparilis Zone to the Upper falsiovalis Zone (MN Zone 2 of Klapper 1985).

\section{Polygnathus cristatus ectypus Huddle, 1934}

Figure $7 \mathrm{H}$

*1934 Polygnathus cristatus eptycus n. subsp. Huddle, p. 103 , pl. 8 , fig. 38 .

1957 Polygnathus cristata Hinde, 1879. - Bischoff \& Ziegler, pp. 86, 87, pl. 15, figs 1, 2-12, 13, 16; pl. 17, figs $12,13$.

1971 Polygnathus cristatus Hinde, 1879. - Orr, p. 48, pl. 6, figs $1,2$.

1992 Polygnathus cristatus Hinde, 1879. - Bardashev, p. 76, pl. 8, figs 22-24.

1994 Polygnathus cristatus Hinde, 1879. - Bai et al., pp. 176,177 , pl. 24, fig. 3.

1999 Polygnathus cristatus Hinde, 1879. - Lazreq, p. 86, pl. 2, fig. 1 .
2003 Polygnathus cristatus eptycus Huddle, 1934. Aboussalam, p. 177, pl. 19, figs 7-9.

2007 Polygnathus cristatus n. subsp. Huddle, 1934. Aboussalam \& Becker, p. 368, figs 9F, G.

2008 Polygnathus cristatus eptycus Huddle, 1934. - Liao \& Valenzuela-Ríos, p. 9, tables 1B, C.

2010 Polygnathus cristatus eptycus Huddle, 1934. - Narkiewicz \& Bultynck, p. 620, tables 2, 6, figs 17.14, 15.

Material. - One specimen from Bed LGA221 $1_{46-51}$, MGUV6170.

Description. - Pa element upper side: slightly asymmetrical, wide oval platform; broken - short? - free blade. Maximum width at the end of the anterior half. High carina with nearly complete fused denticles, but some free tips are observed. Platform ornamented by a chaotic arrangement of coarse nodes at the central part and thinner ones at the margins. Anterior part of the platform has few nodes; smooth anterior margins. Pa element lateral side: flat unit, anteriorly arched. Pa element lower side: Basal pit covered by matrix.

Remarks. - P. c. cristatus has a platform with less sizevariability of nodes that are regularly arranged, in contrast with that of P. c. eptycus.

Stratigraphical distribution. - The subspecies ranges from the base of the Upper hermanni to the transitans Zone (Sandberg et al. 1994); our specimen comes from the top of the Lower fasiovalis Zone.

Polygnathus dengleri dengleri Bischoff \& Ziegler, 1957 Figure 7I, J

*1957 Polygnathus dengleri n. sp.; Bischoff \& Ziegler, p. 87 , pl. 15, figs $14,15,17-24$; pl. 16, figs $1-4$.

1981 Polygnathus dengleri Bischoff \& Ziegler, 1957. Huddle, p. B29, pl. 6, figs 15-23.

2001 Polygnathus dengleri Bischoff \& Ziegler, 1957. Liao et al., p. 26, pl. 4, figs 7-9, 12 (further synonymy).

2007 Polygnathus dengleri dengleri Bischoff \& Ziegler, 1957. - Aboussalam \& Becker, p. 356, fig. 6(C-F).

2010 Polygnathus dengleri dengleri Bischoff \& Ziegler, 1957. - Narkiewicz \& Bultynck, pp. 618, 620, tables 2-4; figs 16.1, 16.2, 17.16, 17.17.

Material. - Eight specimens from samples LGA218'06 ${ }_{45-52}(1)$, LGA219 ${ }_{108-120}(1)$, LGA219 $_{225-240}(1)$,

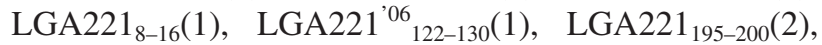
LGA-I/5(1) and LGA-I/6a(1). Figured specimens: MGUV6171 (Fig. 7I; LGA219 225-240) and MGUV6172 (Fig. 7J; LGA221'06 ${ }_{122-130)}$ ). 
Description. - Pa element upper side: oval to spear-shaped, symmetrical and narrow platform. Maximum width close to the anterior half; slender and elongate unit. Blade/platform ratio about $1: 5$. Short free blade with $4-5$, anteriorly inclined denticles; the 2-3 more anterior denticles are higher and sharp. Anterior part of carina composed of fused denticles forming a ridge or of individual denticles; posterior part of carina with 7 rounded and wide spaced or oval denticles connected by a fine ridge. The height of the carina denticles decreases posteriorly. Variable platform ornamentation consists of fine nodes with random arrangement or thin transversal ridges on one side of the carina and small, thin and single nodes combined with fused nodes on the other side. Wide and shallow adcarinal throughs. Pa element lateral side: flat unit slightly arched at both ends; in some specimens, the lateral margins are slightly higher than the carina. The combination of the anterior convex margin and the high and inclination of the denticles confers a wedge shape. Pa element lower side: small to medium size basal pit, with tear to oval-shaped smooth flange; continues to both ends with straight and narrow keels.

Remarks. - P. d. dengleri is probably one of the taxa from the Givetian-Frasnian interval with a high morphological variation. Traditionally, three morphotypes have been distinguished. Klapper (in Johnson et al. 1980, p. 102) distinguished two morphotypes from central Nevada: one form is characterised by a rather coarse and somewhat irregular transversal ridges and nodes and its range is limited to the Lower disparilis Zone (the former Lower dengleri Zone). The other form is characterised by a platform with fine nodes and fewer, weaker transversal ridges. It corresponds to the holotype, and appears in the Upper disparilis Zone (the former Upper dengleri Zone).

Bultynck \& Jacobs (1981, p. 19) have recognised both morphotypes of Klapper (in Johnson et al. 1980) from south-eastern Morocco, which were named " $\beta$ " and " $\gamma$ " forms respectively, and a new one " $\alpha$ " form. The latter is characterised by a longer blade, a sub-triangular shaped platform, somewhat straight anterior margins and coarse and irregular ornamentation, which is restricted at the margins and considered as the earlier form.

Aboussalam \& Becker (2007, p. 369) in MdouraEast(Md-E) section, Tafilat Platform have recognised the characteristics of the " $\alpha$ " form described already by Bultynck \& Jacobs (1981), and erected the new subspecies Polygnathus dengleri sagitta.

The figured specimen (Fig. 7I) is a typical " $\gamma$ " form characterised by a platform ornamented by few nodes, a carina formed by oval to rounded denticles, which are widely spaced posteriorly and by a medium size basal pit, with smooth flange more developed posteriorly. The other specimen (Fig. 7J) is characterised by a narrower and longer platform, with one of the anterior margins lower. The carina consists of a ridge, denticles are distinguished only on the blade and in the posterior carina. Rather small basal pit, located at the end of the anterior platform. This form is considered as the "narrow" form by Klapper (1985).

Stratigraphical distribution - - According to Feist \& Klapper (1985), Narkiewicz \& Bultynck (2010): this taxon ranges from the Upper disparilis Zone to the top of the transitans Zone (MN Zone 4 of Klapper 1985).

\section{Polygnathus hemiansatus Bultynck, 1987} Figure $7 \mathrm{~K}, \mathrm{~L}$

1987 Polygnathus hemiansatus n. sp. Bultynck, pp. 161, 162, pl. 7, figs 16-27; pl. 8, figs 1-7.

2008 Polygnathus hemiansatus Bultynck, 1987. - Liao \& Valenzuela-Ríos, p. 11, tabs 1A, B, figs 4A, B.

2010 Polygnathus hemiansatus Bultynck, 1987. - Gouwy, p. 142 , pl. 5 , figs 12,13 ; pl. 6 , fig. 1 (further synonymy).

2011 Polygnathus hemiansatus Bultynck 1987. - Walliser \& Bultynck, pp. 12, 13, pl. 1, figs 11-17.

Material. - Two specimens from samples LGA180 $10 \mathrm{~cm}$ inf., MGUV6173 and LGA189'06, MGUV6184.

Description. - Pa element upper side: asymmetrical, elongated and somewhat slender platform, with maximum width at the posterior half. Partially broken free blade. Slightly straight carina, composed of 7-12 oval to rounded denticles; anterior denticles are closer and posterior ones are more spaced (Fig. 7L); denticles in specimen in Fig. 7K are fused in a ridge with only tips protruding. Denticles size increases at the central part of the platform. Platform ornamented by fine nodes and fine transversal ridges, with radial distribution. Marked constriction in the outer platform margin, just posterior to the geniculation point, that continues with a rounded platform margin. Less developed inner platform margin that is smooth (Fig. 7K) or serrated, posterior of the geniculation point (Fig. 7L). Outwards strongly bowed outer anterior through margin; less bowed inner one. Non-opposite geniculation points. Sharp posterior end, slightly reclined. Pa element lower side: due to breakage it is not easy to exactly locate the basal pit, but probably sits at the anterior half.

Remarks. - According to Bultynck (1987) and Walliser \& Bultynck (2011), the main characteristics of P. hemiansatus are the strong constriction in the outer platform margin posterior to the geniculation point and the well developed outwards bowing of the outer anterior through margin. The 
degree of development of these characteristics permitted these authors the recognition of three morphotypes: $\alpha, \beta$ and $\gamma$. For details, see comments in Walliser \& Bultynck (2011, pp. 12, 13).

Our specimens from LGA section belong to the " $\gamma$ " form. The figured specimens (Fig. 7K, L) show the typical morphological features: well-developed outer platform margin; bowed outer anterior through; serrated inner platform margin close to the geniculation point; ornamentation consisting of small nodes and fine and discontinued ridges. Our specimens are rather slender and narrow and can be distinguished from the Morocco material in the platform outline.

Stratigraphical distribution. - The range of $P$. hemiansatus starts at the base of the nominal zone, which is the base of the Givetian, and to the top of the semialternas/latifossatus Zone (the former Upper varcus Zone), the transition between Middle to Upper Givetian. According to Walliser \& Bultynck (2011), the range of the three morphotypes is different. The $\alpha$ form is restricted to the lower part of the hemiansatus Zone, $\beta$ and $\gamma$ forms range into the ansatus Zone.

\section{Polygnathus linguiformis klapperi Clausen, Leuteritz \& Ziegler, 1979}

Figure $7 \mathrm{M}$

*1979 Polygnathus linguiformis klapperi n. ssp.; Clausen et al., p. 32, pl. 1, figs 7, 8 .

2001 Polygnathus linguiformis klapperi Clausen et al., 1979. - Liao et al., pp. 28, 29, pl. 2, figs 25-28 (further synonymy).

2008 Polygnathus linguiformis klapperi Clausen et al., 1979. - Liao \& Valenzuela-Ríos, p. 10, tables 1a, 1b, fig. 3B.

2010 Polygnathus linguiformis klapperi Clausen et al., 1979. - Gouwy, p. 144, pl. 6, fig. 11.

2011 Polygnathus linguiformis klapperi Clausen et al., 1979. - Walliser \& Bultynck, p. 15, pl. 3, figs 7, 8.
Material. - 29 specimens from the following beds: LGA167(1), LGA174(1), LGA175(2), LGA178b ${ }^{\circ 06}(3)$, LGA197(4), LGA199a(3), LGA199b(3), LGA200b(1), LGA200c(2), LGA201(2); LGA190(1), LGA189'06(2), LGA186'06(1), LGA184(1), LGA182(2). Figured specimen: LGA167, MGUV6175.

Description. - Pa element upper side: asymmetrical to slightly symmetrical platform with robust and convex margins. Outer platform more developed and higher than inner. A well developed, somewhat long, and narrow sub-triangular tongue at the platform posterior third. Carina formed by fused nodes that are connected by a strong ridge that ends within the tongue. Platform ornamented by transversal ridges or aligned fine nodes. Narrow and deep anterior adcarinal through. The last portion of the outer platform margin meets the tongue by an inflexion. Sharp posterior end of the tongue. Pa element lateral side: both ends of the unit are arched; outer margin higher than the inner. Pa element lower side: heart shaped small-sized basal pit located at the middle of the platform anterior half. Straight anterior keel; smoothly curved posterior keel.

Remarks. - P. l. klapperi is distinguished from P. l. linguiformis by several aspects: 1) rounded platform outline between the outer margin and the tongue; 2) more nodes on the inner platform margin; 3) bigger and robust tongue; 4) rounded posterior end of the tongue.

P. l. klapperi can be distinguished from P. l. weddigei because the latter, has concave-convex margins, asymmetrical platform, less strongly curved carina, more developed outer platform margins and a poorly development of the tongue.

Stratigraphical distribution. - Weddige (1977) cited its lower range starting from the hemiansatus Zone; but according to Bultynck (1987), Belka et al. (1997) and Walliser \& Bultynck (2011) this taxon ranges from the kockelianus Zone to the semialternans/latifossatus Zone.

Figure 7. All scale bars are $200 \mu \mathrm{m}$, except C $(=100 \mu \mathrm{m})$. A - Polygnathus angustipennatus Bischoff \& Ziegler, 1957. Upper and lower views of MGUV6163, Bed LGA178a, kockelianus-ensensis Zone. • B - Polygnathus angusticostatus Wittekindt, 1966. Upper and lower views of MGUV6164, Bed LGA178a, kockelianus-ensensis Zone. • C - Polygnathus ansatus Ziegler \& Klapper, 1976. Upper and lower views of MGUV6165, Bed LGA197, ansatus Zone. • D, E - Polygnathus cristatus cristatus Hinde, 1879. D - upper and lower views of MGUV6168, Bed LGA216a'06, Lower disparilis Zone; E - upper view of MGUV6169, Bed LGA219 $48-56$, Upper disparilis Zone. $•$ F, G - Polygnathus oblongus Weddige, 1977. F - upper and lower views of MGUV6166. Bed LGA168, kockelianus Zone; G - upper and lower views of MGUV6167, Bed LGA168, kockelianus Zone. - H - Polygnathus cristatus ectypus Huddle, 1934. Upper view of MGUV6170, Bed LGA221 $46-51$, Lower falsiovalis Zone. $・$ I, J - Polygnathus dengleri dengleri Bischoff \& Ziegler, 1957. I - upper and lower views of MGUV6171, Bed LGA219 $225-240$, Upper disparilis Zone; J - upper and lower views of MGUV6172, Bed LGA221 122-130, MN Zone 1. K, L- Polygnathus hemiansatus Bultynck, 1987. K - upper view of MGUV6173, Bed LGA180 $10 \mathrm{~cm}$, hemiansatus Zone; L - upper view of MGUV6184, Bed LGA189'06. Lower hermanni Zone. • M - Polygnathus linguiformis klapperi Clausen, Leuteritz \& Ziegler, 1979. Upper and lower views of MGUV6175, Bed LGA167, kockelianus Zone. • N, O - Polygnathus linguiformis mucronatus Wittekindt, 1966. N - upper and lower views of MGUV6176, Bed LGA201 $15 \mathrm{~cm}$, Lower hermanni Zone; O - upper and lower views of MGUV6185, Bed LGA214b $10 \mathrm{~cm}$, Upper hermanni? Zone. • P - Polygnathus linguiformis ssp. Upper and lower views of MGUV6177, Bed LGA171, kockelianus-ensensis Zone. 


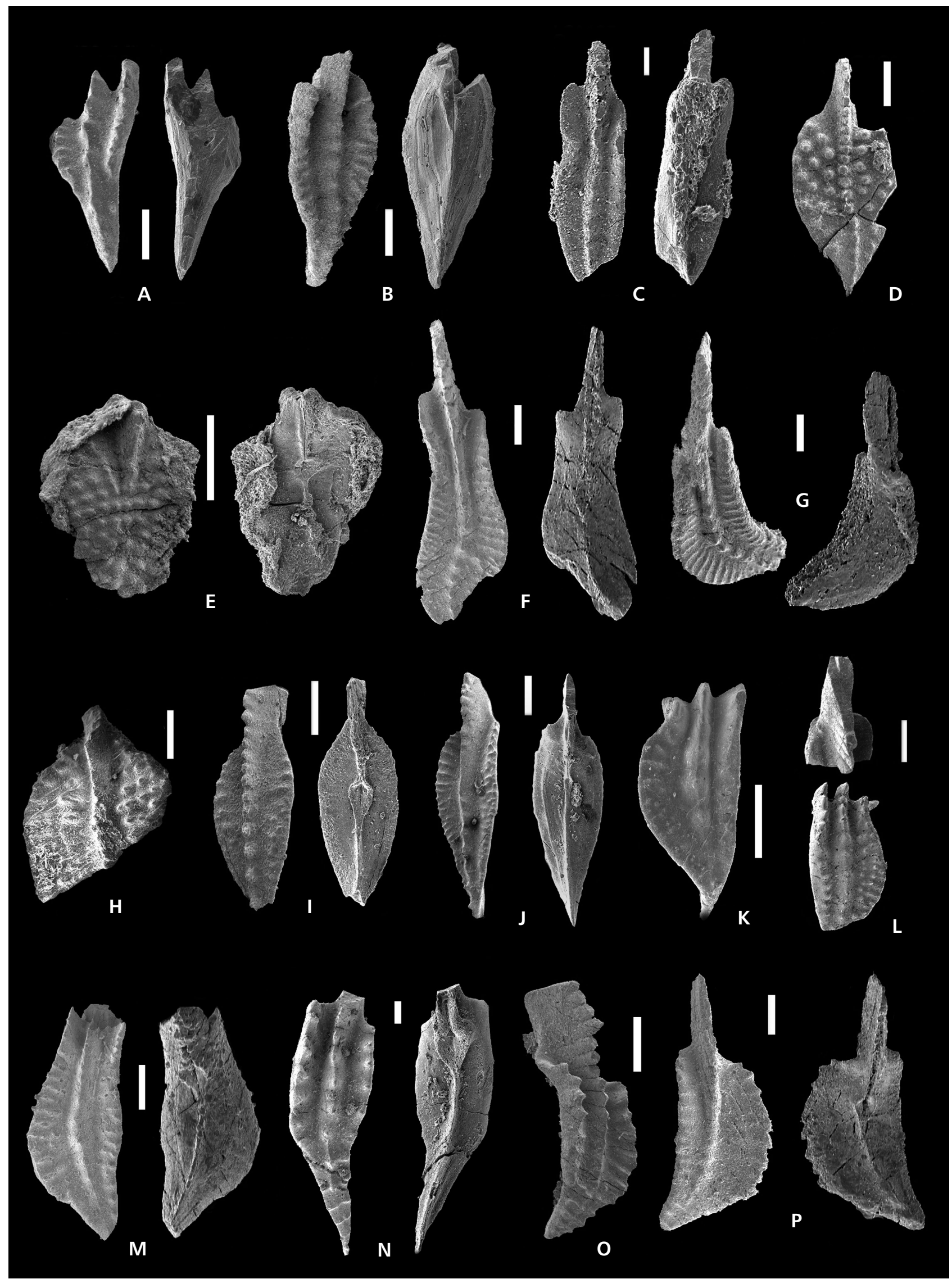




\section{Polygnathus linguiformis mucronatus Wittekindt, 1966}

Figure $7 \mathrm{~N}, \mathrm{O}$

*1966 Polygnathus linguformis mucronata n. subsp. Wittekindt, p. 636, pl. 2, figs 13-15.

2003 Polygnathus linguformis mucronatus Wittekindt, 1966. - Aboussalam, pp. 182, 183, pl. 17, figs 11, 16, 17 (further synonymy).

2008 Polygnathus linguformis mucronatus Wittekindt, 1966. - Liao \& Valenzuela-Ríos, p. 11, fig. 4E, F.

?2010 Polygnathus linguformis mucronatus Wittekindt, 1966. - Gouwy, pp. 144, 145, pl. 6, fig. 9 (further synonymy).

Material. - Two specimens from samples LGA201 $15 \mathrm{~cm}$ inf.

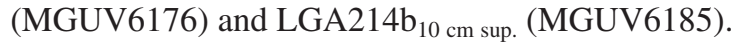

Description. - Pa element upper side: nearly symmetrical and tiny sub-rectangular-shaped platform with parallel margins. Straight free blade with 7 oval and compressed denticles. Carina composed of 8 oval to rounded denticles, which can be fused in a ridge or individually connected. The carina is straight to the tongue and then deflects inward and disappears within the anterior part of the tongue. Narrow subtriangular and sharp tongue, which turns to the inner side and downwards; it bears thin wide spaced transversal ridges that in the anterior part are interrupted by the carina. Platform bears denticulated margins that continue in transversal ridges. Deep adcarinal throughs. Pa element lateral side: strongly arched unit. Denticles height decreases posteriorly. Pa element lower side: oval to heart shaped basal cavity, located at the beginning of the anterior half. Slightly straight anterior basal groove; posterior curved keel.

Remarks. - The main characteristics of this subspecies are the reduced development of the platform, the presence of a narrow tongue which is inwardly and downwards inclined and a basal cavity located in the most anterior part of the platform. According to the shape of the platform outer margin outline and the tongue, we have recognised two forms combining our material and figured specimens from literature. One form, has a straight outline as in Fig. $7 \mathrm{~N}$ or the original specimen of Ziegler \& Klapper (1976, pl. 4, fig. 21) and the other form, has a rounded outline, as in Fig. 70 or the original specimen of Ziegler \& Klapper (1976, pl. 4, fig. 20).

Stratigraphical distribution. - This subspecies appears from the base of the rhenanus/varcus Zone and reaches to the middle part of the semialternans/latifossatus Zone (Weddige 1977).

\section{Polygnathus linguiformis ssp. Figure 7P}

Material. - Only one specimen from Bed LGA171, MGUV6177.

Description. - Pa element upper side: asymmetrical leafshaped platform with weak and short transverse ribs on the margins; outer platform almost double the width of the inner. Blade/platform ratio about $1: 5$. Short and straight free blade with 3-4 fused denticles forming a ridge. Straight anterior carina composed of 3-5 rounded denticles connected by a ridge; slightly curved posterior carina with 6-7 rounded distinct denticles decreasing in size posteriorly and ending at the beginning of the tongue. Small, triangular tongue with transverse ribs, bent to the inner side. Well developed outer margin with rounded and denticulated outline; posterior half inward turned and downwards arched. Anterior platform margins meet the blade at different points; the inner more to the anterior. Pa element lateral side: downwards arched unit, specially the more posterior part. Pa element lower side: Small, symmetrical, round-shaped basal pit with thin flanges. Straight and deep, parallel-sized anterior basal groove; curved, narrow, shallow and weak developed posterior groove.

Remarks. - The combination of outline and short tongue with transverse ribs that interrupt the carina separates our specimen from other known subspecies of $P$. linguiformis.

\section{Polygnathus tafilensis Aboussalam \& Becker, 2007} Figure 8A

2007 Polygnathus tafilensis n. sp. Aboussalam \& Becker, p. 30, fig. 5P-T.

2010 Polygnathus cf. tafilensis Aboussalam \& Becker, 2007. - Gouwy, p. 151, pl. 9, fig. 2.

Material. - One specimen from Bed LGA221 $1_{195-200}$, MGUV6178.

Description. - Pa element upper side: Slightly asymmetrical and flat, leaf-shaped platform. The maximum width of the unit is at the posterior third. Free blade little shorter than the platform, with 10-12 stout denticles fused at the base. The most anterior four denticles are anteriorly oblique-inclined. The last 3-4 denticles of the blade are fused into a thin ridge. Slightly curved carina composed of, at least, 10 partially fused, round-oval denticles, which are connected by a ridge; the height of these denticles decreases to the posterior end. Platform ornamented by fine nodes, randomly distributed on each side of the carina and by short and weakly transverse ridges at the anterior part of the 
platform. Anterior platform margins develop an incipient and short "rostrum". Shallow, short and narrow anterior adcarinal throughs. Outer side of the posterior platform more developed than the inner. Pa element lateral side: flat unit with downwards arched posterior end. Anterior margins higher than posterior ones. Pa element lower side: tiny, heart-shaped basal pit with slightly asymmetrical flanges located at the anterior platform half. Both basal grooves are narrow and parallel-sided; the anterior one straight and anteriorly appressed; the posterior one slightly curved.

Remarks. - The blade/platform ratio distinguished $P$. tafilensis (about $1: 2$ ) from $P$. dubius (1:3). Besides, $P$. dubius has distinctive transverse ridges, a stronger carina, and develops a rostrum.

Our specimen, with the posterior end broken, is closer to the paratypes, than to the holotype.

Stratigraphical and geographical distribution. - According to Aboussalam \& Becker (2007) this species ranges from the dengleri Zone to the top of the pristina Zone (MN Zone 1 of Klapper 1985). Our specimen comes from Bed LGA221 $1_{195-200}$, that belongs to the soluta Zone (MN Zone 2 of Klapper 1985). This taxon has only been recognized in Morocco (Anti-Atlas) and in the Spanish Central Pyrenees.

\section{Polygnathus timorensis Klapper, Philip \& Jackson, 1970}

Figure 8B

*1970 Polygnathus timorensis sp. nov.; Klapper et al., p. 655 , text-fig. $2 \mathrm{a}-\mathrm{d}$, pl. 1, figs $1-3,7-10$ (with synonymy).

1983 Polygnathus timorensis Klapper et al., 1970. - Raven, pl. 3 , fig. 3.

1988 Polygnathus timorensis Klapper et al., 1970. - Sparling, p. 15, figs 18.10 .

1989 Polygnathus timorensis Klapper et al., 1970. - Wang, p. 121, pl. 33, figs 7-9.

1989 Polygnathus ansatus Ziegler \& Klapper, 1970. Wang, pl. 33, fig. 10.

2001 Polygnathus timorensis Klapper et al., 1970. - Liao et al., pp. 38, 39, pl. 4, figs 4-6 (with synonymy).

2008 Polygnathus timorensis Klapper et al., 1970. - Liao \& Valenzuela-Ríos, p. 9, tables 1A, B, figs 3E, F.

2010 Polygnathus timorensis Klapper et al., 1970. Gouwy, pp. 151, 152, pl. 6, figs 2, 3, 5 (with synonymy).

Material. - Five specimens from samples LGA189 ${ }_{15-16}(1)$, LGA184(1), LGA207 10 cm sup.(1), LGA210(1) and LGA212 ${ }^{\prime 06}{ }_{22} \mathrm{~cm}$ inf.(1). Figured specimen: LGA184, MGUV6179.
Description. - Pa element upper side: Narrow, lanceolateshaped, symmetrical platform posterior of anterior trough margins. Sharp posterior end. Free blade partially complete in some specimens shows that the blade is at least half of the total length; the free blade has five (or more) elliptical and laterally compressed denticles, free at their tips. Straight carina with 10-12 sub-elliptical to rounded denticles connected anteriorly by a ridge; posteriorly they are distinct. Denticles size increases and height decreases to the posterior end. Platform ornamented by denticulated margins that reach to the geniculation points. Outer anterior margin more developed than the inner. Smooth adcarinal troughs, deeper anteriorly, which can extend to the posterior end. Inner geniculation point distinctly higher than the outer. Pa element lateral side: Both ends downwards inclined. Platform margins and carina of similar height. Straight and concave inner margin of the anterior trough; strongly downwards inclined outer margin, which is in a more advanced position near the blade. Pa element lower side: Oval-shaped basal pit of medium to small size with symmetrical flanges and located at the most anterior platform. Slightly curved and narrow basal grooves.

Remarks. - The outer anterior trough margin of $P$. timorensis is strongly developed and this character distinguishes it from $P$. ansatus (symmetrical anterior trough margins). Our figured specimen, Fig. 8B has a typical development of the ear-flap structure at the outer anterior trough margin; the position of the basal pit is at the anteriormost part of the platform and the outer geniculation is clearly lower than the inner one.

Stratigraphical distribution. - This species ranges from the base of the timorensis Subzone (the Lower varcus Zone) to the disparilis Zone (Aboussalam 2003); but Aboussalam \& Becker (2007) restricted its range to the ectypus Zone. Our specimens range within the hermanni Zone.

\section{Genus Schmidtognathus Ziegler, 1965}

\section{Schmidtognathus hermanni Ziegler, 1965}

Figure 8C

*1965 Schmidtognathus hermanni n. sp. Ziegler, p. 664, pl. 3, figs 5-26.

1976 Schmidtognathus hermanni Ziegler,1965. - Ziegler et al., tables 6, 9, 13-15, pl. 3, figs 34, 35.

1980 Schmidtognathus hermanni Ziegler, 1965. - Johnson et al., tables 18, 21, pl. 3, figs 27, 28.

1985 Schmidtognathus hermanni Ziegler, 1965. - Ziegler \& Wang, p. 20, pl. 2, figs 13, 14.

1985 Schmidtognathus hermanni Ziegler, 1965. - Bardashev \& Ziegler, pp. 69, 74, pl. 1, figs 30, 31.

1986 Schmidtognathus hermanni Ziegler, 1965. - Hou et al., p. 49, pl. 15, figs $18,19$. 
1989 Schmidtognathus hermanni Ziegler, 1965. - Wang, p. 128 , pl. 41 , figs 6,8 .

1992 Schmidtognathus hermanni Ziegler, 1965. - Bardashev, pp. 51, 52, pl. 6, figs 24, 25.

1994 Schmidtognathus hermanni Ziegler, 1965. - Bai et al., p. 185, pl. 29, fig. 4.

1994 Schmidtognathus hermanni Ziegler, 1965. - Wang, pl. 9, figs 9, 11 .

1995 Schmidtognathus hermanni Ziegler, 1965. Sanz-López, p. 546, pl. 31, figs 11, 13.

2008 Schmidtognathus hermanni Ziegler, 1965. - Liao \& Valenzuela-Ríos, pp. 9, 14, figs 5B, C.

2010 Schmidtognathus hermanni Ziegler, 1965. - Gouwy, pp. 154, 155, pl. 8, figs 8, 9 (further synonymy).

Material. - Eight specimens from samples LGA219 ${ }_{225-240}(7)$, LGA220 $17 \mathrm{~cm}$ sup.(1). Figured specimen: LGA219 $225-240$, MGUV6180.

Description. - Pa element upper side: Symmetrical to asymmetrical, elongate, robust platform with wide-lanceolate shape. The maximum width is at the posterior third. The blade-platform ratio is about $1: 4$. Short and straight free blade composed of 7-8 oval denticles, the three anterior higher. Anterior carina consists of 3-4 oval distinct denticles followed by fused denticles connected by a ridge. Posterior carina with 8-10 individual rounded denticles, which decrease in size. Platform ornamented by two or three longitudinal rows of nodes subparallel to the carina and fine nodes at the margins. Oblique margin troughs on both sides of anterior platform. Pa element lateral side: slightly arched unit with both ends inclined downwards. Pa element lower side: medium to small-sized basal pit, with an anteriorly asymmetric development of the outer flange and a posterior small fold. It is located at the posterior third. Anterior basal groove deeper and wider than posterior.

Remarks. - S. hermanni is distinguished from $S$. wittekindti by the presence of a low and short free blade bearing similar sized denticles, while the latter has a higher cusp at the middle of the blade. Also, the platform outline in S. hermanni varies from rhomboidal to lanceolate shape, the platform outline of $S$. wittekindti is rather triangular. The maximum width in $S$. hermanni is located about the midlenght of the unit, while in $S$. wittekindti is at the anterior third.

The blade-platform ratio in $S$. hermanni is about $1: 4$, while in $S$. pietzneri is about $1: 2$.

The figured specimen, Fig. 8C, has the typical characteristics of $S$. hermanni in the presence of two or three longitudinal rows of nodes, which are subparallel to the carina; small constriction at the anterior platform, and development of shallow anterior troughs. The basal pit is covered by matrix, but other specimens from the same bed exhibit a clearly asymmetrical basal pit.
Stratigraphical distribution. - According to Ziegler (1965, 1971), the range of this species starts in the base of the Lower hermanni Zone and goes up to the Lower falsiovalis Zone; but Klapper \& Johnson (1990) have restricted its upper range to the top of the Upper disparilis Zone.

\section{Schmidtognathus wittekindti Ziegler, 1965 \\ Figure 8D}

*1965 Schmidtognathus wittekindti n. sp. Ziegler, p. 665, pl. 1, fig. 11; pl. 2, figs 1-10.

1970 Schmidtognathus wittekindti Ziegler, 1965. - Kirchgasser, p. 352, lám. 65, figs 3, 7.

1971 Schmidtognathus peracutus (Bryant), 1965. - Orr, p. 56 , pl. 6 , fig. 9 .

1985 Schmidtognathus wittekindti Ziegler, 1965. - Ziegler \& Wang, p. 20, pl. 2, figs 17, 18.

1985 Schmidtognathus wittekindti Ziegler, 1965. - Bardashev \& Ziegler, p. 69, pl. 1, fig. 33.

1986 Schmidtognathus wittekindti Ziegler, 1965. - Hou et al., pp. 49, 50, pl. 16, figs 1, 2, 5-12.

1989 Schmidtognathus wittekindti Ziegler, 1965. - Ji, pl. 2, figs 22, 23.

1989 Schmidtognathus wittekindti Ziegler, 1965. - Wang, p. 129 , pl. 41, fig. 7 .

1992 Schmidtognathus wittekindti Ziegler, 1965. - Bardashev, pp. 51, 52, pl. 6, figs 21-23, 35?.

1994 Schmidtognathus wittekindti Ziegler, 1965. - Wang, pl. 9, figs 5, 10.

1994 Schmidtognathus wittekindti Ziegler, 1965. - Bai et al., p. 185, pl. 29, figs 5, 6 .

1995 Schmidtognathus wittekindti Ziegler, 1965. Sanz-López, p. 546, pl. 31, figs 8, 9.

1995 Schmidtognathus hermanni Ziegler, 1965. - Shen, p. 264, pl. 2, figs 18, 19.

1998 Schmidtognathus wittekindti Ziegler, 1965. - Rogers, p. 732 , fig. 15 .

1999 Schmidtognathus wittekindti Ziegler, 1965. - Lazreq, p. 78, pl. 1, figs 28, 29.

2003 Schmidtognathus wittekindti Ziegler, 1965. - Aboussalam, pp. 193,194, pl. 22, figs 6-10.

2010 Schmidtognathus wittekindti Ziegler, 1965. - Narkiewicz \& Bultynck, figs 17.18, 19.1, 19.2.

Material. - Twelve specimens from beds LGA218 ${ }_{78-88}(1)$ LGA219 $225-240(10)$, LGA220 $17 \mathrm{~cm}$ sup. $(1)$. Figured specimen: LGA219 $225-240$, MGUV6181.

Description. - Pa element upper side: Symmetrical and elongated platform, sub-triangular to arrow-shaped. Maximum width is in the anterior third of the total length. Blade-platform ratio about $1: 4$. Very short free blade bearing 7-11 oval and fused denticles with their sharps ends 


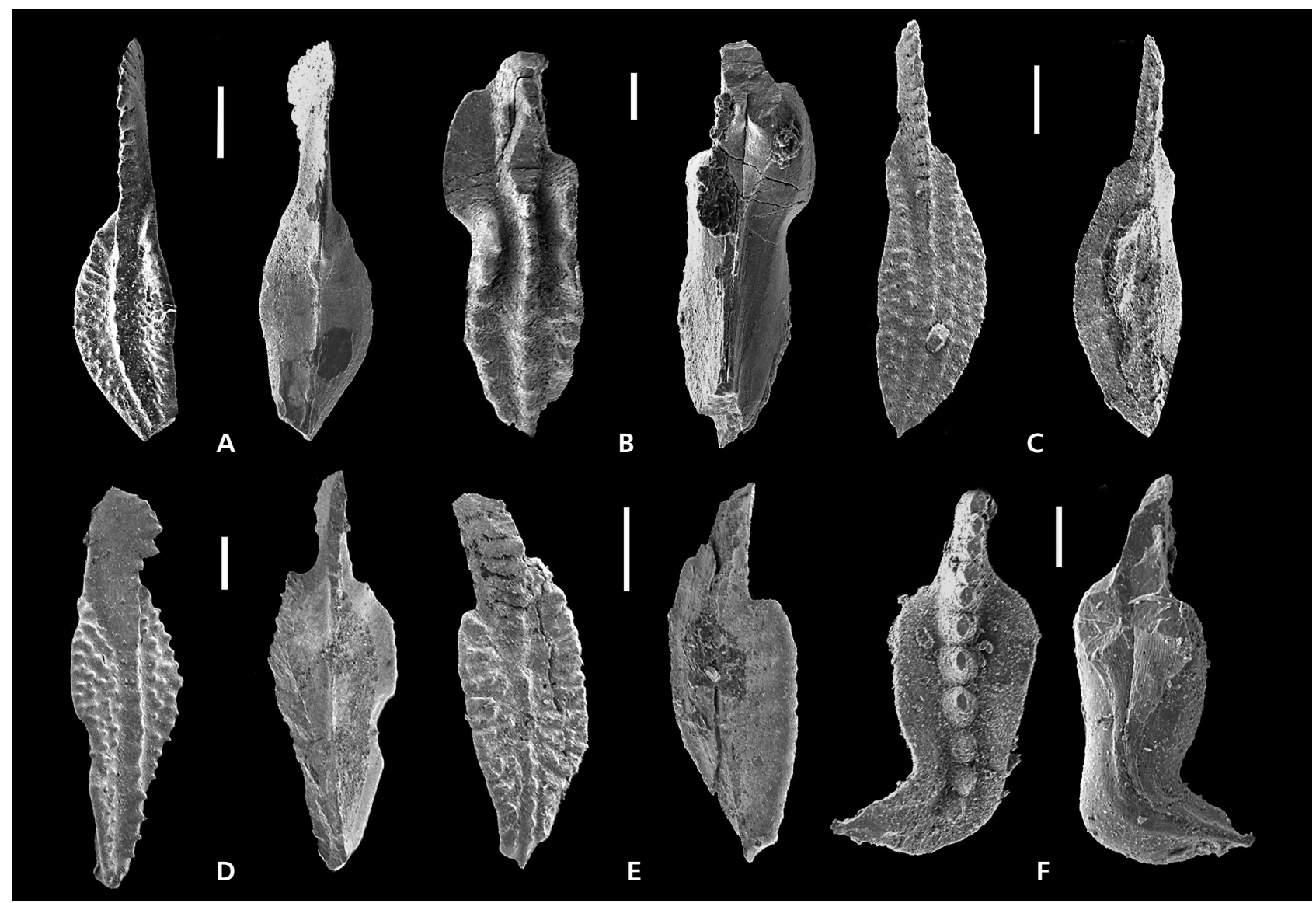

Figure 8. All scale bars are $200 \mu \mathrm{m}$, except B, F $(=100 \mu \mathrm{m})$. A - Polygnathus tafilensis Aboussalam \& Becker, 2007. Upper and lower views of MGUV6178, Bed LGA221 ${ }_{195-200}$, MN Zone 2. • B - Polygnathus timorensis Klapper, Philip \& Jackson, 1970. Upper and lower views of MGUV6179, Bed LGA184, Lower hermanni Zone. • C - Schmidtognathus hermanni Ziegler, 1965. Upper and lower views of MGUV6180, Bed LGA219 $225-240$, Upper disparilis Zone. • D - Schmidtognathus wittekindti Ziegler, 1965. Upper and lower views of MGUV6181, Bed LGA219'06 ${ }_{225-240}$, Upper disparilis Zone. • E - Skeletognathus norrisi Pa element (Uyeno, 1967). Upper and lower views of MGUV6182, Bed LGA-I/1a, norrisi Zone. • F - Tortodus kockelianus kockelianus (Bischoff \& Ziegler, 1957). Upper and lower views of MGUV6183, Bed LGA178a, kockelianus-ensensis Zone.

connected by a fine ridge. Three denticles close to the anterior margin are the highest. Anterior carina formed by fused denticles connected by a ridge that continues from the free blade. Posterior carina with 10-11 partly fused denticles connected by a smooth ridge; posteriorly the spacing is greater. Platform ornamented by fine marginal nodes and two or three longitudinal rows of nodes parallel to the carina. Nodes decrease in size posteriorly. Incipient oblique anterior trough. Pa element lateral side: slightly arched downwards unit. Pa element lower side: Tiny rhomboidal basal pit with a slightly asymmetrical anterior outer flange; it is located at the anterior fourth of the platform. Straight, wide anterior basal groove; straight and high posterior keel.

Remarks. $-S$. wittekindti is distinguished from S. peracutus by the anterior margins and the length of the platform. $S$. peracutus has straight anterior margins and a short platform, while, $S$. wittekindti has rounded margins and a longer platform.
Stratigraphical distribution. - According to Ziegler (1965, 1971) and Hou et al. (1985), the range of this species starts at the base of the Lower hermanni Zone; Klapper \& Johnson (1990) restricted the upper range to the base of the Lower disparilis Zone, but Narkiewicz \& Bultynck (2010) extended the upper range to the lower part of the Upper disparilis Zone.

Our material ranges from the Upper disparilis Zone to the lower part of the falsiovalis Zone.

\section{Genus Skeletognathus Sandberg, Ziegler \& Bultynck, 1989}

\section{Skeletognathus norrisi (Uyeno, 1967)}

Figure 8E

1967 Polygnathus norrisi n. sp.; Uyeno, pp. 10, 11, pl. 2, figs 4,5 . 
1980 Polygnathus norrisi Uyeno, 1967. - Johnson et al., p. 102, pl. 3, fig. 25.

1980 Polygnathus norrisi Uyeno, 1967. - Perri \& Spalleta, pp. 305, 306, pl. 7, figs 5a-6d.

1981 Polygnathus norrisi Uyeno, 1967. - Huddle, p. B31, pl. 19, figs 4,5 .

1989 Skeletognathus norrisi (Uyeno), 1967. - Sandberg et al., p. 214, pl. 5, figs 1-12.

1991 Skeletognathus norrisi (Uyeno), 1967. - Uyeno, p. 156, pl. 3, fig. 19.

1992 Skeletognathus norrisi (Uyeno), 1967. - Bardashev, p. 78, fig-text. 3, pl. 9, fig. 30 .

1993 Skeletognathus norrisi (Uyeno), 1967. - Racki \& Bultynck, tables 2, 4, pl. 3, fig. 10.

1994 Skeletognathus norrisi (Uyeno), 1967. - Bai et al., p. 187 , pl. 29 , figs 7,8 .

1994 Skeletognathus norrisi (Uyeno), 1967. - Kirchgasser, p. 127, pl. 3, figs C, K, M-O.

1995 Skeletognathus norrisi (Uyeno), 1967. - Sanz López, p. 518 , pl. 32, fig. 2.

2001 Skeletognathus norrisi (Uyeno), 1967. - Liao et al., p. 41, pl. 4, figs 22-24.

2003 Skeletognathus norrisi (Uyeno), 1967. - Aboussalam, p. 194, pl. 19, fig. 6.

2005 Skeletognathus norrisi (Uyeno), 1967. - Uyeno \& Wendte, p. 164, text-fig. 8, pl. 2, figs 3, 4.

2006 Skeletognathus norrisi (Uyeno), 1967. - Rodríguez Alfonso, p. 23, pl. 4, figs 1-16, pl. 5, figs 1-7; pl. 6, figs $1-10$.

2007 Skeletognathus norrisi (Uyeno), 1967. - Aboussalam \& Becker, tables 1, 5; figs 8M, S.

2007 Skeletognathus norrisi (Uyeno), 1967. - Narkiewicz \& Bultynck, table 5, fig. 5V.

2008 Skeletognathus norrisi (Uyeno), 1967. - Liao \& Valenzuela-Ríos, p. 14, tab. 1C, figs 2, 6C-F.

2010 Skeletognathus norrisi (Uyeno), 1967. - Gouwy, p. 157 , pl. 9, figs 10, 11.

2010 Skeletognathus norrisi (Uyeno), 1967. - Narkiewicz \& Bultynck, tables 2-4, figs 16.8, 16(19-21).

Material. - Two specimens form beds LGA-I/1a (figured specimen, MGUV6182) and LGA-I/6a.

Description. - Pa element upper side: symmetrical to asymmetrical platform with sub-triangular shape and sharp posterior end; maximum width of the unit at the posterior part. Blade-platform ratio about $1: 2$. Slightly curved free blade (partly broken) with, at least, four individual, elliptic denticles. The slightly curved carina is lower than the blade and consists of an anterior weak ridge that transforms into individual denticles, which decrease in size posteriorly. The two specimens have a different ornamentation showing two distinct morphological features: a subtle "chevron" structure and a concentric irregular arrangement of nodes. The "chev- ron" structure is due to an advanced development stage of the plates or laminae, which are radially distributed and fused. Pa element lateral side: unit smoothly arched downwards. Anterior platform margins somewhat higher than the carina. Pa element lower side: very tiny, oval-shaped, basal pit, located near the anterior part of the platform. Slightly curved, wide anterior keel; narrow posterior keel.

Remarks. - The typical "chevron" structure is a diagnostic characteristic for this species although ornamentation is variable. Our figured specimen differs from the figured specimens in literature by the presence of a longer free blade and more nodes.

Stratigraphical distribution. - This species is restricted to a narrow interval near the Givetian/Frasnian boundary. According to Sandberg et al. (1989), it ranges from the base of the norrisi Zone to the transitans Zone (MN Zone 4 of Klapper 1985); but Klapper \& Johnson (1990) restricted the upper range to the MN Zone 2 of Klapper (1985). Our specimens range from the norrisi Zone (Givetian) to the MN Zone 2 (Lower Frasnian).

\section{Genus Tortodus Weddige, 1977}

\section{Tortodus kockelianus kockelianus (Bischoff \& Ziegler, 1957) \\ Figure 8F}

1957 Polygnathus kockeliana n. sp. Bischoff \& Ziegler, p. 91, pl. 2, figs 1-10; 11, 12 (non).

1966 Polygnathus kockeliana Bischoff \& Ziegler, 1957. Wittekindt, p. 634, pl. 2, fig. 7.

1970 Polygnathus kockeliana Bischoff \& Ziegler, 1957. Seddom, p. 59, pl. 6, figs 1, 2.

1970 Polygnathus kockeliana Bischoff \& Ziegler, 1957. Bultynck, p. 125, pl. 15, fig. 4.

1979 Tortodus kockelianus kockelianus (Bischoff \& Ziegler, 1957). - Lane et al., p. 220, pl. 2, figs 9-11, 14.

1980 Tortodus kockelianus kockelianus (Bischoff \& Ziegler, 1957). - Johnson et al., pl. 3, fig. 21.

1984 Tortodus kockelianus kockelianus (Bischoff \& Ziegler, 1957). - Kim et al., p. 86, pl. 23, fig. 10.

1985 Tortodus kockelianus kockelianus (Bischoff \& Ziegler, 1957). - Ziegler \& Wang, p. 30, pl. 1, figs 20, 21.

1985 Tortodus k. kockelianus (Bischoff \& Ziegler, 1957). Bardashev \& Ziegler, pl. 2, fig. 22.

1987 Tortodus kockelianus kockelianus (Bischoff \& Ziegler, 1957). - Bultynck, p. 180, pl. 9, fig. 17.

1989 Tortodus kockelianus kockelianus (Bischoff \& Ziegler, 1957). - Wang, p. 132, pl. 42, figs 10-12.

1990 Tortodus kockelianus kockelianus (Bischoff \& Ziegler, 1957). - Lazreq, pl. 2, figs 1-4. 
1990 Tortodus kockelianus kockelianus (Bischoff \& Ziegler, 1957). - Bardashev, p. 78, pl. 4, figs 19, 21.

1991 Tortodus kockelianus kockelianus (Bischoff \& Ziegler, 1957). - Uyeno, p. 156, pl. 3, fig. 15.

1995 Tortodus kockelianus kockelianus (Bischoff \& Ziegler, 1957). - Sánz-López, p. 477, pl. 24, figs 6-8.

2010 Tortodus kockelianus kockelianus (Bischoff \& Ziegler, 1957). - Gouwy, pp. 159, 160, pl. 4, figs 10a, b (with synonymy).

Material. - Only one specimen from Bed LGA178a, MGUV6183.

Description. - Pa element upper side: element partly complete with sub-triangular shape. Platform outline varies from symmetrical in the anterior part to asymmetrical in the most posterior part. Maximum width of the platform is in the anterior third. Incomplete anterior blade bears at least four elliptic denticles. Slightly curved carina at the anterior end and sinuous at the posterior part. It is composed of seven elliptical to rounded denticles; their height decreases posteriorly. Smooth platform surface with a strong outwards torsion in the posterior third. Pa element lateral side: the posterior end of the unit is slightly arched downwards. Pa element lower side: large-sized slightly asymmetrical basal cavity located in the widest part of platform. The posterior basal groove is wider anteriorly and narrower and bent outwards.

Remarks. - The figured specimen is close to the holotype and paratypes, but differs somewhat, in having a shorter platform-posterior-end than the holotype.

Tortodus k. kockelianus is distinguished from other species by the presence of elliptic to rounded denticles decreasing in height posteriorly, and by the strong platform inflexion in the posterior part.

Stratigraphical distribution. - T. k. kockelianus ranges from the base of the kockelianus Zone to the ensensis Zone the uppermost Eifelian part. Our specimen occurs at the top of the ensensis Zone.

\section{Acknowledgements}

This work represents a contribution to IGCP-596 and has been supported by the Spanish Research Project CGL2011-24775. The DAAD (J-C. L) and the Alexander von Humboldt-Stiftung (JIV-R) supported earlier activities of this research. We thank the careful reviews of Jeff Over and Pierre Bultynck that helped to improve the initial version. Gil Klapper provided helpful remarks regarding $P$. oblongus and $P$. parawebbi. We are grateful to the SCSIE (Servicio Central de Soporte a la Investigación Experimental) of University of Valencia for technical support. Carlos Martínez-Pérez, Peter Königshof, Dodo Dojen, Devon and Pirata assisted in some of the field seasons.

\section{References}

Aboussalam, Z.S. 2003. Das "Taghanic-Event" im höheren Mittlel-Devon von West-Europa und Marokko. Münstersche Forschungen zur Geologie und Paläontologie 25, 1-330.

Aboussalam, Z.S. \& BecKer, R.T. 2007. New Upper Givetian to basal Frasnian conodont faunas from the Tafilalt (Anti-Atlas, Southern Morocco). Geological Quaterly 51, 345-374.

BAI, S.L., BAI, Z.Q., MA, X.P., WANG, D.R. \& Sun, Y.L. (eds) 1994. Conodont zonation and correlation, bio-event and chemo-event, Milankovitch cycle and nickel-episode. Devonian Events and Biostratigraphy of South China. 303 pp. Peking University Press, Peking.

BARDASHEV, I.A. 1990. Stratigraphy and conodonts of the Eifelian deposits of Central Tajikistan, 25-41. In KHALYm-BADZHA, V.J. (ed.) Conodonts of the USSR Eifelian Stage. Kazan.

Bardashev, I.A. 1992. Conodont Stratigraphy of Middle Asian Middle Devonian. Courier Forschungsinstitut Senckenberg 154, 31-84.

BARDASHEV, I.A. \& ZiEgLeR, W. 1985. Conodonts from a Middle Devonian section in Tadzhikistan (Kalagach Formation, Middle Asia, USSR). Courier Forschungsinstitut Senckenberg 75, 65-78.

Belka, Z., Kaufmann, B. \& Bultynck, P. 1997. Conodont-based quantitative biostratigraphy for the Eifelian of the eastern Anti-Atlas, Morocco. Geological Society of America Bulletin 109, 643-651.

DOI 10.1130/0016-7606(1997)109<0643:CBQBFT>2.3.CO;2

Benfrika, E.M. \& Bultynck, P. 2003. Lower to Middle Devonian conodonts from the Oued Cherrat area and its southern extension (North-Western Meseta, Morocco). Courier Forschungsinstitut Senckenberg 242, 209-215.

BischOFF, G. \& ZiEgLER, W. 1957. Die Conodontenchronologie des Mitteldevons und des tiefsten Oberdevons. Abhandlungen des Hessischen Landesamtes für Bodenforschung 22, 1-136.

BoERSMA, K.T. 1973. Devonian and Lower Carboniferous conodont biostratigraphy, Spanish Central Pyrenees. Leidse Geologische Mededelingen 49, 303-377.

Branson, E.B. \& Mehl, M.G. 1934. Conodont from the Grassy Creek shale of Missouri. University of Missouri Studies 8, 171-259. [imprint 1933]

Branson, E.B. \& Mehl, M.G. 1938. The conodont genus Icriodus and its stratigraphic distribution. Journal of Paleontology 12, 156-166.

BRYANT, W.L. 1921. The Genesee conodont with descriptions of new species. Bulletin of the Bufalo Society of Natural Sciences $13,1-59$.

BultYNCK, P. 1970. Révision stratigraphique et paléontologique (Conodontes et Brachiopodes) de la Coupe type du Couvinien. Mémoires de l'Institut Géologique de l'Université de Louvain 26, 1-152.

Bultynck, P. 1985. Lower Devonian (Emsian) - Middle Devonian (Eifelian and lowermost Givetian) conodont successions from the Ma'der and the Tafilalt, southern Morocco. Courier Forschungsinstitut Senckenberg 75, 261-286.

Bultynck, P. 1986. Accuracy and reliability of conodont zones: the Polygnathus asymmetricus "zone" and the Givetian-Frasnian boundary. Bulletin de L'Institut royal des Sciences naturelles de Belgique 56, 269-280. 
Bultynck, P. 1987. Pelagic and neritic conodont successions from the Givetian of pre-Sahara Morocco and the Ardennes. Bulletin de L'Institut royal des Sciences naturelles de Belgique, Sciences de la Terre 57, 149-181.

Bultynck, P. 2003. Devonian Icriodontidae: biostratigraphy, classification and remarks on paleoecology and dispersal. Revista Española de Micropaleontología 35, 295-314.

Bultynck, P. \& JACOBS, L. 1981. Conodonts et sédimentologie des couches de passage du Givetien au Frasnian dans le Nord du Tafilalt et dans le Ma'der (Maroc présaharien). Bulletin de L'Institut royal des Sciences naturelles de Belgique, Sciences de la Terre 53, 1-24.

Clausen, C.-D., Leuteritz, K. \& Ziegler, W. 1979. Biostratigraphie und Lithofazies am Südrand der Elsper Mulde (hohes Mittel- und tiefes Oberdevon; Sauerland, Rheinisches Sciefergebirge). Geologie Jahrbuch A-51, 3-37.

Flass, G. 1966. Die Mittledevon/Oberdevon-Grenze im Paläozoikum von Graz. Neues Jarburch Geologie und Paläontologie, Abhanlungen 124, 221-240.

GARCíA-LÓPEZ, S. 1986. Los conodontos y su aplicación al estudio de las divisiones cronostratigráficas mayores del Devónico Asturleones (España). Publicaciones Especiales del Boletín Geológico y Minero, Instituto Geológico y Minero de España, $1-112$.

García-López, S. \& Sanz-López, J. 2002. Devonian to Lower Carboniferous conodont biostratigraphy of the Bernesga Valley section (Cantabrian Zone, NW Spain), 163-205. In García-López, S. \& Bastida, F. (eds) Paleozoic conodonts from Northern Spain. Cuadernos del Museo Geominero 1. 438 pp. Instituto Geológico y Minero de España, Madrid.

Glenister, B.F. \& KLAPPER, G. 1966. Upper Devonian conodonts from the Canning Basin, Western Australia. Journal of Paleontology 40, 777-842.

Gouwy, S. 2004. The Graphic Correlation Method as a tool for integrated stratigraphy. Application to the uppermost Emsian-lowermost Famennian (Devonian) from the Ardenne Area (Belgium-N-France) and correlation with the eastern Anti-Atlas (Morocco) and the New York Area (N-America). 214 pp. PhD thesis, Catholic University of Leuven, Belgium.

Gouwy, S. 2010. Middle Devonian Conodonts from the northwestern margin of Gondwana. $199 \mathrm{pp} . \mathrm{PhD}$ thesis, University of Modena and Reggio Emilia, Italy and University of Valencia, Spain.

Gouwy, S. \& Bultynck, P. 2003. Conodont based graphic correlation of the Middle Devonian formations of the Ardenne (Belgium): Implications for stratigraphy and construction of a regional composite. Revista Española de Micropaleontología $35,315-344$.

Gouwy, S., Liao, J.-C. \& Valenzuela-Ríos, J.I. 2013. Eifelian (Middle Devonian) to Lower Frasnian (Upper Devonian) conodont biostratigraphy in the Villech section (Spanish Central Pyrenees). Bulletin of Geosciences 88(2), 315-338. DOI 10.3140/bull.geosci.1341

HindE, G.J. 1879. On conodonts from the Chazy and Cincinnati group of the Hamilton and Genesee-shale divisions of the Devonian in Canada and he United States. Quaterly Journal of the Geological Society of London 35, 351-369.

DOI 10.1144/GSL.JGS.1879.035.01-04.23
Hou, H.F., Ji, Q., Wang, J.X., WANG, R.G. \& Zhang, Z.X. 1985. Biostratigraphy near the Middle-Upper Devonian boundary in Maanshan section, Guangxi, South China. Courier Forschungsinstitut Senckenberg 75, 39-52.

Hou, H.F., Ji, Q., WANG, J.X. \& WANG, R.G. 1986. Middle-Upper Devonian boundary in Maansan of Xiangzhou, Guangxi. 137 pp. Geological Publising House, Bejing.

HuddLE, J.W. 1934. Conodonts from the New Albany Shale of Indiana. Bulletin of American Paleontology 21, 1-136.

Huddle, J.W. \& Repetski, J.E. 1981. Conodonts from the Genesee Formation in western New York. Geological Survey Professional Papers 1032-B, 1-66.

HüNeKe, H. 1995. Early Devonian (Emsian) to Late Devonian (Famennian) stratigraphy and conodont of the Antoinettenweg section in the Lower Harz Mountain (Germany). Courier Forschungsinstitut Senckenberg 188, 99-131.

IzokH, N.G., YolKin, E.A. \& BAKHAREv, N.K. 2004. Early Frasnian conodonts from the Rudny Altai (West Siberia). News on Paleontology and Stratigraphy, Geology and Geophysic 45, 89-101. [in Russian]

JI, Q. 1989. On the Frasnian Conodont Biostratigraphy in the Guilin Area of Guangxi, South China. Courier Forschungsinstitut Senckenberg 117, 303-320.

Ji, Q. \& ZIEGLER, W. 1993. The Lali Section: An excellent reference section for Upper Devonian in South China. Courier Forschungsinstitut Senckenberg 157, 1-183.

Ji, Q., ZiEgler, W. \& Dong, X. 1992. Middle and Late Devonian conodonts from the Licun Section Yongfu, Guangxi, South China. Courier Forschungsinstitute Senckenberg 154, 85-105.

Johnson, J.G. 1990. Lower and Middle Devonian brachiopoddominated communities of Nevada, and their position in a biofacies-province-realm model (with a section on Revision of Middle Devonian conodont zones, by G. Klapper and J.G. Johnson). Journal of Paleontology 64, 902-941.

Johnson, J.G., KLAPPeR, G. \& Trojan, W.R. 1980. Braquiopod and conodont succesions in the Devonian of the northern Antelope Range, central Nevada. Geologica et Palaeontologica $14,77-116$.

Khalymbadzha, V.G. \& Chernysheva, N.G. 1970. Konodonty v. Ancyrodella iz devonskikh otloherniy volgo-kamskogo kraia i ikh stratigraficheskoe znachenie, 81-103. In UlianALENINA, V.I. (ed.) Biostratigrafia $i$ paleontologia paleozoiskikh otloszheniy vostoka russkoj plataformia i zapadnogo Priuralia. Kazanskiy ordena trudovogo krasnogo znameni gosudarstvenniy universitet, Kazan.

Kim, A.I., Erina, M.V., Apekina, L.S. \& Lesovaya, A.I. 1984. Devonian biostratigraphy of the Zeravshano-Hissar Mountain Region. 94 pp. Fan, Tashkent.

KirChgasser, W.T. 1970. Conodonts from near the Middle/Upper Devonian boundary in North Cornwall. Journal of Paleontology 13, 335-354.

KirCHGASSER, W.T. 1994. Early morphotypes of Ancyrodella rotundiloba at the Middle-Upper Devonian boundary, Genesee Formation, west central New York. Bulletin of New York Society Museum 481, 117-134.

KLAPPER, G. 1985. Sequence in the conodont genus Ancyrodella in the Lower asymmetricus Zone (earliest Frasnian, Upper Devonian) of the Montagne Noire, France. Palaeontographica, Abteilung A 188, 19-34. 
KLAPPER, G. 1989. The Montaigne Noire Frasnian (Upper Devonian) conodont succession, 449-468. In McMillan, N.J., Embry, D.J. \& Glass, D.J. (eds) Devonian of the World, Proceedings of the Second International Symposium on the Devonian System. Canadian Society of Petroleum Geologists 14. [imprint 1988]

KLAPPER, G. \& BARRick, J.E. 1983. Middle Devonian (Eifelian) conodonts from the Spillville Formation in northern Iowa and southern Minnesota. Journal of Paleontology 57, 1212-1243.

Klapper, G., Philip, G.M. \& JACKson, J.H. 1970. Revision of the Polygnathus varcus Group (Conodonta, Middle Devonian). Neues Jahrbuch für Geologie und Paläontologie, Monatshefte, 650-667.

KLAPPER, G. \& ZiEGLER, W. 1977. Distribution of conodonts in Lower/Middle Devonian boundary beds of the Barrandian. Unpublished report, Field Conference of the International Subcommission on Devonian Stratigraphy. 4 pp. Prague.

KLUG, C.R. 1982. Devonian stratigraphy and conodont biostratigraphy from portions of two cores in Central Iowa. Iowa Geological Survey, Open File Report 82-2, 1-56.

Lane, H.R., Müller, K.J. \& Ziegler, W. 1979. Devonian and Carboniferous conodonts from the Perak Malaysia. Geologica et Palaeontologica 13, 213-226.

LAZReQ, N. 1990. Devonian conodonts from Central Morocco. Courier Forschungsinstitut Senckenberg 118, 65-79.

LAZREQ, N. 1999. Biostratigraphie des conodontes du Givétien au Famennien du Maroc central - Biofaciès et événement Kellwasser. Courier Forschungsinstitut Senckenberg 214, $1-111$.

Liao, J.-C., Königshof, P., Valenzuela-Ríos, J.I. \& Schindler, E. 2008. Depositional environment interpretation and development of the Renanué section (Upper Eifelian-Lower Frasnian; Aragonian Pyrenees, N. Spain). Bulletin of Geosciences 83(4), 481-490. DOI 10.3140/bull.geosci.2008.04.481

Liao, J.-C. \& Valenzuela-Ríos, J.I. 2008. Givetian and early Frasnian conodonts from the Compte section (Middle-Upper Devonian, Spanish Central Pyrenees). Geological Quarterly $52,1-18$.

Liao, J.-C. \& Valenzuela-Ríos, J.I. 2012. Upper Givetian and Frasnian (Middle and Upper Devonian) conodonts from Ampriú (Aragonian Pyrenees, Spain): Global correlations and palaeogeographical relations. Paleontology 55, 819-842.

Liao, J.-C., Valenzuela-Ríos, J.I. \& Rodríguez, S. 2001. Descripción de los conodontos del Givetiense y Frasniense inferior (Devónico) de Renanué (Pirineos Aragoneses). Coloquios de Paleontología 52, 13-45.

Martínez-Pérez, C., Valenzuela-Ríos, J.I., Navas-Parejo, P., LiaO, J.-C. \& Botell, H. 2011. Emsian (Lower Devonian) Polygnathids (Conodont) succession in the Spanish Central Pyrenees. Journal of Iberian Geology 37, 45-64.

Mawson, R. \& TALENT, J.A. 1989. Late Emsian-Givetian stratigraphy and conodont biofacies - carbonate slope and offshore shoal to sheltered lagoon and nearshore carbonate ramp - Broken River, North Queensland, Australia. Courier Forschungsinstitut Senckenberg 117, 205-259.

MeY, P.H.W. 1967. Evolution of the Pyrenean basins during the Late Paleozoic, 1157-1166. In OswALD, D.H. (ed.) International Symposium on the Devonian System. 1376 pp. Alberta Society of Petroleum Geologists, Calgary.
Montesinos, J.R. \& Sanz-López, J. 1999. Ammonooideos del Devónico Inferior y Medio en el Pirineo oriental y central. Antecedentes históricos y nuevos hallazgos. Revista Española de Paleontología, No. extr. Homenaje al Prof. J. Trujols, 97-108.

Murphy, M.A., Valenzuela-Ríos, J.I. \& Carls, P. 2004. On classification of Pridoli (Late Silurian)-Lochkovian (Early Devonian) Spathognathodontidae (Conodonts). University of California, Riverside, Campus Museum Contribution 6, 1-25.

Narkiewicz, K. \& Bultynck, P. 2007. Conodont biostratigraphy of shallow marine Givetian deposits from the Radom-Lublin area, SE Poland. Geological Quaterly 51, 419-442.

Narkiewicz, K. \& Bultynck, P. 2010. The Upper Givetian (Middle Devonian) subterminus conodont Zone in North America, Europe and North Africa. Journal of Paleontology 84, 588-625. DOI 10.1666/10-029.1

NarkiEwicZ, K. \& NarkiewicZ, M. 1998. Conodont evidence for the Mid-Givetian Taghanic Event in south-eastern Poland. Paleontologica Polonica 58, 213-223.

Narkiewicz, K. \& NARKIEwICZ, M. 2008. The mid-Frasnian subsidence pulse in the Lublin Basin (SE Poland): sedimentary record, conodont biostratigraphy and regional significance. Acta Geologica Polonica 58, 287-301.

OrR, W.R. 1964. Conodonts from the Devonian Lingle and Alto formations of southern Illinois. Illinois State Geological Survey $361,1-28$.

ORR, W.R. 1971. Conodonts from Middle Devonian Strata of the Michigan Basin. Geological Survey Bulletin of State of Indiana Department 45, 1-110.

OrR, W.R. \& KLAPPER, G. 1968. Two new conodont species from Middle-Upper Devonian boundary beds of Indiana and New York. Journal of Paleontology 42, 1066-1075.

Over, D.J. 2007. Conodont biostratigraphy of the Chattanooga Shale, Middle and Upper Devonian, southern Appalachian Basin, eastern United States. Journal of Paleontology 81, 1194-1217. DOI 10.1666/06-056R.1

Over, D.J., Hopkins, T.H., Brill, A. \& Spaziani, A.L. 2003. Age of the Middlesex Shale (Upper Devonian, Frasnian) in New York State. Courier Forschungsinstitut Senckenberg 242, 217-223.

Ovnatanova, N.S. \& Kononova, L.I. 2008. Frasnian conodonts from the eastern Russian Platform. Paleontological Journal 42, 997-1166. DOI 10.1134/S0031030108100018

Ovnatanova, N.S. \& KuZ'Min, A. V. 1991. Knonodonty tipovykh razrezov Domanikovoy svity na yuzhnom Timane. Izvestiya Akademii Nauk SSSR Seriya Geologicheskaya 1991, $37-50$.

Perri, M.C. \& Spalleta, C. 1980. Conodonti e biozonatura del Frasniano (Devoniano sup.) di Pramosio, Alpi Carniche. Bolletino della Società Paleontologica Italiana 19, 281-310.

Pollock, C.A. 1968. Lower Upper Devonian conodonts from Alberta, Canada. Journal of Paleontology 42, 415-443.

Pyle, L.J., Orchard, M.J., Barnes, C.R. \& Landry, M.L. 2003. Conodont biostratigraphy of the Lower to Middle Devonian Deserters Formation (new), Road River Group, northeastern British Columbia. Canadian Journal of Earth Science 40, 99-113.

Racki, G. \& BUltynck, P. 1993. Conodont biostratigraphy of the Middle to Upper Devonian boundary beds in the Kielce area of the Holy Cross Mts. Acta Geologica Polonica 43, 1-25. 
Raven, J.G. 1983. Conodont biostratigraphy and depositional history of the Middle Devonian to Lower Carboniferous in the Cantabrian Zone (Cantabrian Mountains, Spain). 339 pp. $\mathrm{PhD}$ thesis, University of Leiden, Holland.

Rogers, F.S. 1998. Conodont biostratigraphy of the Little Cedar and Lower Coralville formations of the Cedar Valley Group (Middle Devonian) of Iowa and significance of a new species of Polygnathus. Journal of Paleontology 72, 726-737.

Sandberg, C.A., Hasenmueller, N.R. \& Rexroad, C.B. 1994. Conodont biochronology, biostratigraphy, and biofacies of Upper Devonian Part of New Albany Shale, Indiana. Courier Forschungsinstitut Senckenberg 168, 227-253.

Sandberg, C.A., Ziegler, W. \& Bultynck, P. 1989. New standard conodont zones and early Ancyrodella phylogeny across Middle-Devonian boundary. Courier Forschungsinstitut Senckenberg 110, 195-230.

SANZ-LÓPEZ, J. 1995. Estratigrafía y bioestratigrafia (Conodontos) del Silúrico Superior-Carbonífero Inferior del Pirineos Oriental y Central. 514 pp. PhD thesis, University of Barcelona, Spain.

SchÖNLAUB, H.P. 1985. Devonian conodonts from section Oberbuchach II in the Carnic Alps (Austria). Courier Forschungsinstitut Senckenberg 75, 353-374.

Seddon, G. 1970. Pre-Chappel conodonts of the Llano Region, Texas. Bureau of Economic Geology, The University of Texas, Austin, Report of Investigations 68, 1-113.

SHEN, J.-W. 1995. Middle-Upper Devonian conodont succession and sea-level change in Guilin. Acta Micropalaeontologica Sinica 12, 251-273.

Sparling, D.R. 1981. Middle Devonian conodont apparatuses with seven types of elements. Journal of Paleontology 55, 295-316.

SPARLING, D.R. 1983. Conodont biostratigraphy and biofacies of lower Middle Devonian limestones, north-central Ohio. Journal of Paleontology 57, 825-864.

Sparling, D.R. 1988. Middle Devonian stratigraphy and conodont biostratigraphy, north-central Ohio. Ohio Journal of Science 88, 2-18.

Sparling, D.R. 1999. Conodont from the Prout Dolomite of north-central Ohio and Givetian (Upper Middle Devonian) correlation problems. Journal of Paleontology 73, 892-907.

UlRICH, E.O. \& BASSLER, R.S. 1926. A classification of the toothlike fossils, conodonts, with descriptions of American Devonian and Mississippian species. Proceedings of the United States Natural Museum 68, 12.

Uyeno, T.T. 1967. Conodont zonation, Waterways Formation (Upper Devonian), north-eastern central Alberta. Geological Survey of Canada, Paper 67-30, 1-20.

Uyeno, T.T. 1974. Conodont of the Waterways Formation (Upper Devonian) of northeastern and central Alberta. Geological Survey of Canada, Bulletin 232, 1-93.

Uyeno, T.T. 1982. Systematic conodont paleontology, 73-95. In Norris, A.W., Uyeno, T.T. \& McCABE, H.R. Devonian rocks of the Lake Winnipegosis-Lake Manitoba outcrop belt, Manitoba. Chapter 3. Geological Survey of Canada, Memoir 392, $1-280$.

Uyeno, T.T. 1991. Pre-Famennian Devonian conodont biostratigraphy of selected intervals in the eastern Canadian Cordillera. Geological Survey of Canada, Bulletin 417, 129-161.
Uyeno, T.T. \& Wendte, J. 2005. Conodont biostratigraphy and physical stratigraphy in two wells of the Beaverhill Lake Group, upper Middle to lower Upper Devonian. Bulletins of American Paleontology 369, 151-171.

Valenzuela-Ríos, J.I. \& SANZ-LóPeZ, J. 2002. Pyrenees, 86-89. In GibBons, W. \& Moreno, T. (eds) The Geology of Spain. 649 pp. Geological Society of London, London.

Vandelaer, E., Vandormael, C. \& Bultynck, P. 1989. Biofacies and refinement of conodont succession in the Lower Frasnian (Upper Devonian) of the type area (Frasnes-Nismes, Belgium). Courier Forschungsinstitut Senckenberg 117, 321-352.

Walliser, O.H. \& Bultynck, P. 2011. Extinctions, survival and innovations of conodont species during the Kacák Episode (Eifelian-Givetian) in south-eastern Morocco. Bulletin de L'Institut royal des Sciences naturelles de Belgique 81, $5-25$.

WANG, C.Y. 1989. Devonian conodonts of Guangxi. Memoirs of Nanjing Institute of Geology and Palaeontology, Academia Sinica 25, 1-152.

WANG, C.Y. 1994. Application of the Frasnian standart conodont zonation in South China. Courier Forschungsinstitut Senckenberg 168, 83-130.

WeARY, D.J. \& HarRis, A.G. 1994. Early Frasnian (Late Devonian) conodonts from the Harrell Shale, Western Foreland Fold-and-Thrust Belt, West Virginia, Maryland, and Pennsylvania Appalachians, U.S.A. Courier Forschungsinstitut Senckenberg 168, 195-225.

Weddige, K. 1977. Die conodonten der Eifel Stufe im Typusgebiet und in benachbarten Faciesgebieten. Senckenbergiana lethaea 58, 271-419.

WitTeKindt, H. 1965. Zur Conodontenchronologie des Mitteldevons. Fortschritte in der Geologie von Rheinland und Westfalen 9, 621-646.

XIONG, J.F. 1980. Conodonts, 80-100. In XIAN, S.Y., WANG, S.D., Zhou, X.Y., XIONG, J.F. \& ZhouY, T.R. (eds) Nandan typical stratigraphy and paleontology of Devonian in China. The People's Publishing House of Guizhou, Guiyang, China.

ZIEGLER, W. 1965. Eine Verfeinerung der Conodontengliederung an der Grenze Mittel-/Oberdevon. Fortschritte in der Geologie von Rheinland und Westfalen 9, 647-676.

ZIEGLER, W. 1971. Conodont stratigraphy of European Devonian. Geological Society of America, Memoir 127, 227-284.

Ziegler, W. \& Klapper, G. 1964. In Ziegler, W., KlapPer, G. \& LindströM, M. The validity of the name Polygnathus (Conodonta, Devonian and Lower Carboniferous). Journal of Palaeontology 38, 421-423.

Ziegler, W. \& Klapper, G. 1976. In Ziegler, W., Klapper, G. \& Johnson, J.G. Redefinition and subdivision of the varcus-Zone (Conodonts, Middle-?Upper Devonian in Europe and North America. Geologica et Palaeontologica 10, 109-140.

Ziegler, W. \& SANDBERG, C.A. 1990. The Late Devonian standard conodont zonation. Courier Forschungsinstitut Senckenberg 121, 1-115.

ZIEGLER, W. \& WANG, C.Y. 1985. Sihongshan section, a regional reference section for the Lower-Middle and Middle-Upper Devonian boundaries in East Asia. Courier Forschungsinstitut Senckenberg 75, 17-38. 